\title{
Neural protein synthesis during aging: effects on plasticity and memory
}

\author{
Lesley A. Schimanski' and Carol A. Barnes ${ }^{1,2,3 *}$ \\ ' Evelyn F. McKnight Brain Institute and Division of Neural Systems, Memory and Aging, Arizona Research Laboratories, University of Arizona, Tucson, AZ, USA \\ 2 Department of Psychology, University of Arizona, Tucson, AZ, USA \\ ${ }^{3}$ Department of Neurology, University of Arizona, Tucson, AZ, USA
}

\section{Edited by:}

Thomas C. Foster, University of Florida, USA

\section{Reviewed by:}

Ángel M. Carrión, Universidad Pablo de Olavide de Sevilla, Spain

Thomas C. Foster, University of Florida, USA

\section{${ }^{*}$ Correspondence}

Carol A. Barnes, Evelyn F. McKnight Brain Institute, Life Sciences North Building, room 355, PO Box 245115 University of Arizona, Tucson, AZ 85724-5115, USA.

e-mail: carol@nsma.arizona.edu
During aging, many experience a decline in cognitive function that includes memory loss. The encoding of long-term memories depends on new protein synthesis, and this is also reduced during aging. Thus, it is possible that changes in the regulation of protein synthesis contribute to the memory impairments observed in older animals. Several lines of evidence support this hypothesis. For instance, protein synthesis is required for a longer period following learning to establish long-term memory in aged rodents. Also, under some conditions, synaptic activity or pharmacological activation can induce de novo protein synthesis and lasting changes in synaptic transmission in aged, but not young, rodents; the opposite results can be observed in other conditions. These changes in plasticity likely play a role in manifesting the altered place field properties observed in awake and behaving aged rats. The collective evidence suggests a link between memory loss and the regulation of protein synthesis in senescence. In fact, pharmaceuticals that target the signaling pathways required for induction of protein synthesis have improved memory, synaptic plasticity, and place cell properties in aged animals. We suggest that a better understanding of the mechanisms that lead to different protein expression patterns in the neural circuits that change as a function of age will enable the development of more effective therapeutic treatments for memory loss.

Keywords: protein synthesis, translation, transcription, aging, hippocampus, memory, plasticity, place cells
The idea that changes in the amount of protein synthesis in the brain might explain some of the cognitive effects of aging began to be tested in the 1960s (Flexner et al., 1962, 1963, 1967). Methodologies advanced during the ensuing two decades, but the general strategy was to determine rates of translation by measuring the amounts of particular amino acids that were incorporated into protein using in vivo or in vitro preparations of whole brain or selected brain structures. As more and more brain-specific proteins and their putative roles were discovered, it became evident that expression of individual proteins could either increase or decrease with age, and that the rates of change across the lifespan could also differ between proteins. Following the discovery that de novo protein synthesis is necessary for the establishment of long-term information storage, experiments were designed to examine translation of individual proteins in restricted regions of the brain, and in response to cognitive or artificial stimulation. It also became apparent that regulation of transcription undergoes age-related changes, and that increases or decreases in transcription, translation, or both determine the expression of a given protein at any point during the lifespan.

The focus of this review is on hippocampal learning and memory, how it changes with age, and the contributions made to agerelated cognitive decline by plasticity mechanisms that require protein synthesis. First, studies of overall brain protein synthesis levels are reviewed, and then age-related changes in expression of specific mRNAs and proteins thought to have important roles in plasticity and memory are described. The effects of age-dependent reduced translation on memory and long-lasting forms of synaptic plasticity will be considered, as well as the consequences of altered long-term plasticity on spatial information processing and memory. Lastly, pharmaceutical interventions are discussed that enhance age-related memory loss by modifying signaling pathways that elicit new protein synthesis, and new drug targets for alleviating cognitive aging are suggested based on recently discovered mechanisms of long-lasting synaptic plasticity.

\section{TRANSCRIPTION AND TRANSLATION IN THE AGING BRAIN REDUCED NEURAL PROTEIN SYNTHESIS RATE DURING AGING}

It was not until the 1980s that methods for routinely obtaining accurate measurements of brain proteins became standardized and reliable. Prior to this time, the experimental methods did not consider specific activity of the precursor pool (reviewed by Richardson and Birchenall-Sparks, 1983), which resulted in highly variable outcomes across studies. Using improved methodology, several groups found that levels of brain protein synthesis increase during development in the rodent, reaching maximum levels sometime during the first 6 months of age, and then decline thereafter (Dwyer et al., 1980; Ekstrom et al., 1980; Fando et al., 1980; Ingvar et al., 1985; Smith et al., 1995; but see Filion and Laughrea, 1985; reviewed by Richardson, 1981; Richardson and Birchenall-Sparks, 1983; Richardson et al., 1983). A similar pattern was observed in the white leghorn chicken (Yang et al., 1977). There is some disagreement pertaining to the exact time course of the decline, with some 
finding a greater rate of decline in translation during adulthood (Ekstrom et al., 1980; Fando et al., 1980; Ingvar et al., 1985; Smith et al., 1995), and others finding the greatest rate of decline during senescence (Dwyer et al., 1980). Similarly, although protein synthesis decline has been observed in many other types of tissues and cells (e.g., liver, kidney, muscle), the time courses and rates of decline vary (reviewed by Webster, 1985). In spite of the fact that there remains some disagreement on the timing of the accelerated decline in brain tissue, there is agreement that translation is reduced as animals age. It is important to note here that most of these studies examined rates of translation in the brains of animals that were not manipulated or cognitively activated prior to measurement, or in non-perturbed in vitro preparations. Thus, the measurements obtained from the foregoing experiments reveal resting rates of synthesis that may or may not reflect rates occurring when the system is activated.

Ingvar et al. (1985) thoroughly examined levels of protein synthesis in a wide range of brain structures during aging, and a decade later followed this up with a second report that calculated these levels more accurately (Smith et al., 1995). Age-related declines (6 month vs. 15- to 23-month-old Sprague-Dawley rats) were found in the olfactory cortex, the internal capsule, cerebellar white matter, and brain structures having roles in the auditory, visual, and extrapyramidal motor systems. The authors concluded that protein synthesis is particularly affected in sensory and extrapyramidal motor systems during aging, however, an alternate interpretation of this result is that activity in sensorimotor circuitry might be reduced because of reduced locomotion in aged animals. Although Ingvar et al. suggested that regions required for higher cognitive function are relatively spared, they did find age-related protein synthesis declines in the hippocampal dentate gyrus region (but not area CA1), the nucleus accumbens, and the locus coeruleus, regions that mediate and module learning and memory. Several explanations might be offered for the decreased rate of protein synthesis in the dentate gyrus, including reduced synaptic terminals in this area in aged animals (Geinisman et al., 1977, 1978, 1992), or reduced rates of neurogenesis (Kuhn et al., 1996). Although the absolute rates of translation reported were quite different, Smith et al. (1995) largely confirmed the conclusions that Ingvar et al. (1985) had made a decade earlier, and the relative differences found between groups and brain structures remained similar.

\section{AGE-RELATED TRANSCRIPTIONAL CHANGES}

Although it is clear that general protein expression levels in specific brain structures can change during the aging process, more mechanistic insight is derived from examining the expression of individual proteins that are known to have roles in synaptic plasticity and memory. Bishop et al. (2010) review several signaling pathways that exhibit evolutionarily conserved up- or down-regulation of gene expression. In general, genes involved in regulating mitochondrial function, neural plasticity and synaptic function are down-regulated during aging, whereas those required for stress and immune/inflammatory responses are up-regulated. In fact, although the overall level of protein synthesis in hippocampal area CA1 remains constant (Smith et al., 1995), the expression levels of numerous individual genes and proteins either increase or decrease in this brain region during aging.
Indeed, the translation of specific proteins is preceded by transcription of the mRNAs that encode these proteins, which can also undergo age-related change. In order to understand the origin of age-related changes in protein expression, research methods have adapted to measure both protein and mRNA synthesis. By combining methodologies such as immunohistochemistry, in situ hybridization, real-time quantitative reverse transcriptase polymerase chain reaction (RT-PCR), microarray analysis, and laser capture dissection, amounts of specific proteins and mRNAs can be measured in discrete brain regions and even in single cells. Whereas early studies measured general expression levels in gross tissue samples, it can now be discerned whether particular mRNAs or proteins undergo age-related changes in expression specifically in neurons or in glial cells within subregions of brain structures. Of particular interest are those studies that have examined expression associated with a time-locked event, whether artificial (i.e., electrical stimulation of neural circuitry) or naturalistic (e.g., exploratory behavior).

The immediate-early genes (IEGs) encode transcription factors that regulate expression of their target genes, and effector proteins that directly influence the state of the cell (reviewed by Sheng and Greenberg, 1990; Guzowski, 2002). They are activated rapidly and transiently by patterned synaptic activity (Cole et al., 1989; Dragunow et al. 1989), and function to induce transcription independently of protein synthesis, although termination of this transcription does require protein synthesis (Sheng and Greenberg, 1990; Guzowski, 2002).

Of the IEGs that function as transcription factors, zif268 is quite interesting as it is up-regulated $10 \mathrm{~min}$ to $2 \mathrm{~h}$ after stimuli that induce long-term potentiation (LTP) (Cole et al., 1989; Richardson et al., 1992). Thus, it is active during the time that LTP transitions from its early state into its longer-lasting (late), protein synthesisdependent state (Abraham et al., 1991; Abraham and Williams, 2003, 2008; and see Jones et al., 2001, for evidence that zif268 has a role in late LTP in the dentate gyrus). Consistent with this time course of activation, zif268 expression is required for long-term, but not short-term, memory (Jones et al., 2001). zif268 expression is also increased in the hippocampus by foraging behaviors (Wallace et al., 1995). Together, these patterns of expression suggest that zif268 may play a central role in activating transcription of genes necessary for hippocampus-dependent long-term memory.

Does zif268 activity change in senescence? Yau et al. (1996) demonstrated that resting levels of zif268 mRNA are decreased in hippocampal areas CA1 and CA2, and in the neocortex, of aged animals. Also, fewer aged CA1 cells express Zif268 protein, but the proportion of Zif268-positive cells at rest does not correlate with spatial learning in the Morris water maze (Desjardins et al., 1997). Blalock et al. (2003) later showed in a microarray study that in area CA1, there are reduced levels zif268 mRNA at rest in aged rats that expressed deficits in spatial learning as a group. These data indicate that zif268 expression changes with age, and may contribute to agerelated deficits in hippocampus-dependent memory.

c-Fos is another IEG-encoded protein that can act as a transcription factor (Morgan et al., 1987; Morgan and Curran, 1991), and it likely has a role in learning and memory (Grimm et al., 1997; Guzowski and McGaugh, 1997). Like zif268, c-fos expression can be up-regulated by stimuli that elicit LTP, learning, and exploration of a novel environment (Worley et al., 1993; see reviews by 
Herdegen and Leah, 1998; Hughes et al., 1999). Also like zif268, $c$-fos expression changes in senescence, but the story is less consistent. In fact, the proportion of cells in the dorsal hippocampus that show expression of c-Fos protein at rest does not change with age (Desjardins et al., 1997). However, Touzani et al. (2003) found that fewer CA1 and CA3 cells were positive for c-Fos protein in aged than in young rats 6 days after learning in a radial arm maze. No differences were found between young and old 30 days after learning, nor at either time point in the dentate gyrus. However, using a semi-quantitative reverse Northern strategy that confers enhanced sensitivity to low levels of mRNA, Lanahan et al. (1997) found that following LTP induction in the hippocampus, $c$-fos mRNA expression is enhanced to a greater degree in aged than in young rats.

One of the most-studied IEGs in terms of plasticity and memory function is activity-regulated cytoskeleton-associated protein (Arc). Whereas zif268 and $c$-fos encode transcription factors and are found near the nucleus, Arc is an effector protein that coprecipitates with actin, and has been suggested to contribute to structural plasticity in dendrites (Lyford et al., 1995). In fact, Arc can be targeted to dendrites engaged in synaptic activity (Steward et al., 1998), and this pattern of expression is not affected by protein synthesis inhibition (Wallace et al., 1998). Arc expression at activated synapses can be achieved by high-frequency electrical stimulation, exposure to psychomotor stimulants, odor and visual stimulation, exploration of environments, and Pavlovian conditioning (Steward et al., 1998; Tan et al., 2000; Pinaud et al., 2001; Steward and Worley, 2001; Petrovich et al., 2005; Tagawa et al., 2005; Zou and Buck, 2006). It also appears that Arc has a lasting influence on memory formation: Arc blockade selectively impairs LTP maintenance and long-term memory without affecting LTP induction nor short-term memory (Guzowski et al., 2000).

Hippocampal Arc expression does change with age. Fewer hippocampal granule cells express Arc mRNA following exploratory behavior in old rats (Small et al., 2004). Blalock et al. (2003) also found reduced resting Arc expression in CA1 of old rats using microarray analysis. Penner et al. (2010a) confirmed these results by combining methods for quantifying single-cell RNA expression in one hemisphere (catFISH, Guzowski et al., 1999) with RT-PCR analysis in the other. While there are fewer granule cells that express $A r c$, there is no change in the number of cells expressing Arc in aged CA1. For CA1, however, there is a reduction in transcription of Arc per CA1 neuron in aged rats. Although Arc expression can be upregulated when the aged hippocampus is activated, its consistently diminished presence across behavioral states may reduce capacity for long-term changes in hippocampal synaptic structure. Such age-related changes could negatively impact hippocampal function dependent memory consolidation.

Other IEGs that are involved in hippocampal memory and plasticity have potential roles in cognitive aging (e.g., AP-1, Narp, Cox-2, BDNF, tPA, Homer1A, Rheb), but their expression across the lifespan has not yet been examined in enough depth for definitive conclusions (but see Lanahan et al., 1997; Blalock et al., 2003; Pang and Lu, 2004). What can be said, however, is that several IEGs likely have selective roles in long-term memory: disruption of c-Fos, tPA, Zif268, or Arc does not affect learning or short-term memory, but impairs memory consolidation (reviewed by Guzowski, 2002). Nevertheless, it is possible to have reduced levels of transcription yet similar levels of protein, and vice versa. It will be necessary to examine both transcriptional and translational changes across the lifespan to pinpoint whether the locus of age-related change in expression of a protein is at the stage of RNA or protein synthesis. In the end, however, it is the protein that "does the work," and whose expression and activity must be examined, in order to begin to understand the causes of cognitive aging.

\section{AGE-RELATED CHANGES IN PROTEIN SYNTHESIS AFFECT MEMORY LONG-TERM MEMORY REQUIRES PROTEIN SYNTHESIS}

The early work by Flexner and colleagues first demonstrated the importance of protein synthesis in the long-term consolidation of memory. Using puromycin, they were able to show that, for several days after training, new protein synthesis in the temporal lobe is crucial for the later expression of long-term memory (Flexner et al., 1962, 1963, 1967). This study also suggested that protein synthesis is required in the neocortex at later time points for memory consolidation. It later became evident that inhibition of protein synthesis during training left immediate learning and short-term memory (which occurs within a timeframe of minutes to hours) intact, but prevented the stabilization of memory for longer time periods.

Among the early studies was one conducted by Squire and Barondes (1973) who showed that mice could learn an object discrimination task while treated with cycloheximide, a protein synthesis inhibitor; however, these same mice exhibited retention deficits when tested $24 \mathrm{~h}$ later. A consensus therefore began to emerge that under conditions of $80-90 \%$ cerebral protein synthesis inhibition, acquisition and initial performance on memory tasks is left intact, but retention becomes progressively impaired thereafter, with significant impairment observed days or weeks after training (e.g., Davis and Squire, 1984). More recent studies have confirmed these findings, and provide further insight into the time course of protein synthesis requirements following a learning event. Injection of the protein synthesis inhibitor anisomycin immediately following training results in impaired hippocampus-dependent long-term (24-h) memory for contextual fear conditioning and inhibitory avoidance learning in mice and rats, respectively (Bourtchouladze et al., 1998; Quevedo et al., 2004), and injection 30-min before training results in 24-h (but not 30-min) social recognition memory impairment in mice (Kogan et al., 2000). Some studies also indicate that during a later interval ( $4 \mathrm{~h}$ after training) protein synthesis is required for memory consolidation when a weak training protocol is used (Bourtchouladze et al., 1998). This is mirrored by a requirement for mRNA synthesis immediately after, and 3-6 h after training, for long-term memory in an inhibitory avoidance paradigm (Igaz et al., 2002).

While there are clearly experimental design issues that arise due to toxicity and potential "non-specific effects" of protein synthesis disruption (Alberini, 2008; Hernandez and Abel, 2008) the observation of reduced levels of protein synthesis in aged organisms began to suggest that the ability to form new long-term memories might be particularly vulnerable in advanced age.

\section{SOME FORMS OF LONG-TERM MEMORY ARE REDUCED IN SENESCENCE}

Normal aging is often accompanied by memory impairment (for review see Rosenzweig and Barnes, 2003; Burke and Barnes, 2006). Although many forms of memory are left intact by the aging process, 
age-related deficits have been identified in several types of hippocampus-dependent memory, including spatial memory (e.g., Barnes et al., 1980; McIntyre and Craik, 1987; Spencer and Raz, 1995), fear memory (e.g., Houston et al., 1999; Ward et al., 1999) and trace eyeblink conditioning (e.g., Finkbiner and Woodruff-Pak, 1991; Solomon and Groccia-Ellison, 1996; Thompson et al., 1996; Kishimoto et al., 2001; Knuttinen et al., 2001). Importantly, these hippocampal function dependent memory deficits have been observed across phylogeny, including mouse, rat, rabbit, dog, monkey, and human; as such, mechanisms of age-related memory deficits may be meaningfully studied in detail in the rodent as a precursor to further primate studies.

Barnes and McNaughton (1985) demonstrated an accelerated rate of decline of spatial memory in aged rats that paralleled more rapid decay of LTP at the perforant path-granule cell synapse. Further studies have indicated that there is a tendency for aged rodents to exhibit greater deficits in some types of long-term memory than in short-term memory (Winocur, 1988a). Aged rats show selective deficits 21 days, but not $1 \mathrm{~h}$, after training when tested for recall of a passive avoidance response (Winocur, 1988b). In the Morris water maze, if multiple swim trials are conducted each day for several concurrent days, a "saw-toothed" pattern of performance emerges for aged but not young rats (Foster, 1999). This pattern results from performance improvements from trial to trial when the elapsed time between trials is short, but a decline in performance on the first trial the following day (after a long interval between trials); there is little evidence of this decline in young rats (Gage et al., 1984; Rapp et al., 1987; Diana et al., 1995).

Oler and Markus (1998) investigated the time course of hippocampal memory consolidation in young (4 month), middle aged (10 month), and old (23 month) F344 rats. Rats underwent contextual fear conditioning and were given retention tests 10 and 52 days later. These time points were chosen to examine memory when the hippocampus is necessary for memory expression (10 days) and when the memory is presumably stored in neocortical circuitry (52 days) (Kim and Fanselow, 1992; see also Anagnostaras et al., 1999). There were no age differences in retention 10 days after conditioning, but the conditioned fear response increased between 10 and 52 days in young rats, whereas it decreased in old rats. This pattern of retention in young rats may be considered a "memory incubation" effect in which increases are observed for some time following an aversive stimulus without further exposure to it, possibly counteracting forgetting. Houston et al. (1999) examined conditioned fear memory in different age groups using similar methods. Again, there were no age differences in fear memory 1 day after conditioning, but after 20 days a similar pattern emerged with increased fear memory in young rats but decreased fear memory in old rats. There are several possible explanations for these results. There may be an age-related decrease in either the efficiency or the duration of hippocampus-dependent consolidation processes (e.g., protein synthesis-dependent mechanisms) that interfere with normal memory formation in aged rats. Alternatively, the processes that enable a gradual transformation of episodic memory over time to produce the memory incubation effect seen in young rats could be diminished in old rats. The data are also consistent with the possibility of faster forgetting in old rats, which may be independent of consolidation.
A further study of contextual fear memory by Ward et al. (1999) suggests that aged rats do not exhibit better memory for information encoded long before hippocampal lesions as opposed to soon before lesions, as is observed in young rats. Rather, aged rats exhibited contextual fear impairment during all retention intervals tested between 1 and 28 days after training. Ward et al. (1999) suggest that memory impairments were seen during early retention tests in this study but not that of Oler and Markus (1998) due to differences in training; old rats in the Ward et al. (1999) study were slower to learn the association between context and shock, perhaps reflecting age-related hippocampal deficits in spatial and contextual processing. Overall, these fear conditioning studies indicate that aged rats can show intact acquisition and initial memory for a contextual fear association, but impaired long-term memory may result from altered consolidation processes (see also Houston et al., 1999).

Thus, it appears that in some tasks that depend on an intact hippocampus, the mechanisms required for learning can be largely intact. However, age-related changes in processes necessary for memory stabilization show vulnerability to the aging process.

\section{PROTEIN SYNTHESIS-DEPENDENT MEMORY IN AGED ORGANISMS}

There are indications that the time course of protein synthesisdependent memory consolidation might be extended in aged rodents. Davis et al. (1981) injected mice with anisomycin either before or immediately after training in a passive avoidance task. These injections impaired memory 7 days later in young (2-3 month), middle aged (6-7 month), and older (14-15 month) mice. However, injections 10-min after training impaired 7-day memory in only the old group, although the time course of whole brain protein synthesis inhibition was similar between all three age groups. Mizumori et al. (1985) extended this experiment with longer time intervals in even older mice (17-20 months), and again found that the older mice showed a longer time interval over which impairments of memory could be observed via inhibition of protein synthesis (up to $30 \mathrm{~min}$ after training). Another way to inhibit protein synthesis in the brain during a discrete time interval (typically hours) is to give electroconvulsive shock (ECS). Essman (1982) found that when training was followed immediately by ECS, memory for a conditioned response was reduced over a 48 -h retention interval in $6,12,18$, and 24-month-old mice. However, when ECS was given 20-min after training, memory was impaired only in 18- and 24-month-old mice. Essman then evaluated the effects of ECS on the rate of protein synthesis in limbic structures, and found that it was reduced $1 \mathrm{~h}$ after ECS in all age groups, but after $12 \mathrm{~h}$ was reduced only in 18- and 24-month-old mice.

From these data, Essman suggested that memory consolidation processes may be slowed in aged mice as a consequence of cellular/ metabolic changes, and/or a slowdown in protein synthesis may impair the consolidation of memory traces. Overall, the authors of these studies interpret these findings to indicate that the transition time from short- to long-term memory is extended during aging, suggesting that a longer time period after training may be required in order for memory consolidation to be successful.

Several more recent studies have examined age-related changes in cAMP responsive element binding protein (CREB) activity as a potential cause of memory impairment in aging. CREB is a 
transcription factor whose activity is required for hippocampal memory consolidation (Guzowski and McGaugh, 1997; Impey et al., 1998; Silva et al., 1998; Shaywitz and Greenberg, 1999; Taubenfeld et al., 1999; Kogan et al., 2000; Tully et al., 2003; Frankland et al., 2004; Brightwell et al., 2005). CREB is active when phosphorylated (pCREB; Gonzalez and Montminy, 1989), and can be up-regulated by the induction of LTP (Bito et al., 1996; Deisseroth et al., 1996; Impey et al., 1996; Schulz et al., 1999) and learning (Impey et al., 1998; Taubenfeld et al., 1999). pCREB stimulates the expression of proteins thought to promote long-lasting forms of synaptic plasticity and memory (reviewed by Bailey et al., 1996; Yin and Tully, 1996), and several studies have indicated that pCREB activity is reduced in aged rodents. Monti et al. (2005) studied hippocampal resting CREB expression, and pCREB expression following fear conditioning, in 5- and 30-month-old male Wistar rats. No agerelated changes in resting CREB expression were found, but its level of phosphorylation was higher in aged animals. Aged animals exhibited impaired fear memory 24 -h after conditioning, and that time the ratio of pCREB to CREB was increased in young but not aged rats. Furthermore, resting expression of CREB-binding protein (CBP, a CREB co-activator) is also reduced in the hippocampus of aged rats (Chung et al., 2002), potentially blunting the propensity for pCREB to elicit transcription during aging. In fact, the expression of Arc and the transcription factor CCAAT enhancer binding protein $\beta$ (C/EBP $\beta$ ), whose expression is thought to be activated by pCREB (Niehof et al., 1997; Athos et al., 2002), also increased more in young than in aged rats following fear conditioning. Porte et al. (2008) also found lower numbers of pCREB-immunoreactive cells in dorsal hippocampal area CA1 and the dentate gyrus 15-min after spatial learning in memory-impaired aged mice.

Countryman and Gold (2007) utilized a social transmission of food preferences task to probe age-related differences in memory at different post-training delays in the rat. Young (3-month) and aged (32-month) Fischer 344/Brown Norway F1 hybrid rats were tested for memory immediately, 24-h, 48-h, 72-h, and 1-week after training. The groups performed comparably on the immediate and 24-h tests, but aged rats showed reduced memory thereafter. When CREB was measured at rest, the number of CREB-immunoreactive cells was lower in area CA3 of the ventral hippocampus in aged rats than in young rats. The numbers of pCREB-immunoreactive cells in dorsal CA1 and ventral dentate gyrus were also lower in aged rats. pCREB- but not CREB-immunoreactive cells in most hippocampal regions increased dramatically after training in both age groups, but these increases were significantly less in dorsal CA1 and ventral dentate gyrus, CA3, and CA1 in old rats. Thus, in this study, age differences in the activation status of CREB are more dramatic than those in resting expression of CREB.

Mouravlev et al. (2006) manipulated CREB expression using a recombinant adeno-associated virus vector. Rats were injected with vector at 8 weeks of age to transgenically express CREB or the inducible cAMP early repressor (ICER) in the dorsal hippocampus. No effects of transfection were found at 3 months of age in spatial and passive avoidance memory, but by 15 months of age overexpression of CREB resulted in enhanced memory, and overexpression of ICER led to reduced memory in 24-h and 3-day (but not 10-min) retention tests. Although this study provides a strong indication that CREB activity interacts with age-related memory changes, further studies will be required to determine whether a later onset of CREB or ICER overexpression can affect memory with age, and whether acute (rather than chronic) CREB overexpression can also enhance memory in aged rats.

Collectively, there is a large body of evidence for a decline in long-term memory in aged animals, including hippocampal deficits in spatial memory, trace eyeblink conditioning, and contextual fear memory. The intra-hippocampal mechanisms that underlie impaired long-term memory during aging are less clear, but evidence is mounting that irregularities in CREB-dependent transcription are a key contributor in this memory decline. These findings converge with those showing an altered time course of protein synthesis inhibition to suggest that the regulation of protein synthesis differs in aged animals, resulting in a reduced capacity for long-term memory.

\section{PROPERTIES OF LONG-LASTING FORMS OF SYNAPTIC PLASTICITY ARE ALTERED IN ADVANCED AGE}

Long-term potentiation (LTP) is an activity-dependent enhancement of synaptic transmission (Bliss and Lomo, 1973) that is a putative cellular mechanism of learning and memory. Long-term depression (LTD), alternately, is a reduction in strength of synaptic transmission that is typically elicited by different patterns of activity than LTP. LTP and LTD have primarily been studied through the application of patterned electrical stimuli to synaptic pathways ex vivo (i.e., in brain slices) or in vivo (i.e., using surgically-implanted electrodes in anesthetized or awake animals). Using in vivo methods, changes in synaptic transmission similar to LTP have been shown to accompany learning (e.g., Gruart et al., 2006). Although these methods do not exactly mimic the more synaptically diffuse patterns of activity thought to occur naturally (although see Whitlock et al., 2006) they have been quite useful in examining cellular and molecular activity that contributes to the consolidation of plastic changes.

\section{LONG-LASTING LTP DEPENDS ON THE INITIATION OF NEW PROTEIN SYNTHESIS}

Different forms of LTP can be induced by distinct patterns of stimuli; early-LTP (E-LTP) can last minutes to hours and is thought to relate mechanistically to short-term memory, whereas late-LTP (L-LTP) can last hours to days and relies on mechanisms that parallel those of long-term memory (Abraham and Williams, 2003, 2008). Of particular interest is the fact that L-LTP in the dentate gyrus and hippocampal area CA1 requires new protein synthesis for a brief period of time after induction (Krug et al., 1984; Stanton and Sarvey, 1984; Montarolo et al., 1986; Frey et al., 1988; Otani et al., 1989, 1992; Nguyen et al., 1994; Mullany and Lynch, 1997) as does long-term memory (see previous sections). By applying selective inhibitors of mRNA synthesis (e.g., actinomycin D), it has been determined that de novo synthesis of mRNA is not required for LTP maintenance for up to $3 \mathrm{~h}$ after tetanic stimulation (Otani et al., 1989; Frey et al., 1996; Raymond et al., 2000), indicating that any new proteins required up to this point can be translated from preexisting mRNAs (including the possibility of local protein synthesis of dendritic mRNA). This transcription-independent time interval has been suggested as an intermediate phase of LTP (Raymond et al., 2000; Abraham and Williams, 2008). However, new mRNAs 
are necessary for LTP maintenance lasting $5 \mathrm{~h}$ or longer in the dentate gyrus and CA1 (Frey et al., 1996), suggesting that L-LTP is dependent on both transcription and translation.

There is evidence that LTD also participates in hippocampusdependent memory formation (reviewed by Kemp and ManahanVaughan, 2007). A protein synthesis-dependent late phase of LTD has been identified (Manahan-Vaughan et al., 2000; Sajikumar and Frey, 2004), which may also be vulnerable to the changes observed in protein synthesis during aging. However, it might be that a particular balance between protein synthesis and degradation of particular proteins is required for long-term maintenance of LTP and LTD at synapses, and not just new protein synthesis per se (e.g., Fonseca et al., 2006a,b; reviewed by Abraham and Williams, 2008).

\section{ALTERED LONG-LASTING PLASTICITY IN AGED ANIMALS}

Long-term potentiation induction using weak stimulation patterns elicits lower levels of synaptic modification in aged than in young rodents (in vitro: Deupree et al., 1993; Moore et al., 1993; Rosenzweig et al., 1997). Similarly, Gruart et al. (2008) found a gradual increase in the synaptic field potential during learning in a trace eyeblink conditioning paradigm in young mice, whereas old mice exhibited neither significant learning nor changes in field potential magnitude. However, induction of LTP with strong patterns of high-frequency electrical stimulation is typically intact in aged animals (in vivo awake preparation: Barnes, 1979; anesthetized preparation: Landfield et al., 1978; Landfield, 1980; Applegate and Landfield, 1988; in vitro preparation: Landfield and Lynch, 1977; Chang et al., 1991; Deupree et al., 1991; Moore et al., 1993; Diana et al., 1994a,b; Barnes et al., 1996a; Norris et al., 1996; Shankar et al., 1998; but see awake: Gruart et al., 2008; anesthetized: Lynch and Voss, 1994; McGahon et al., 1997; Murray and Lynch, 1998a,b; in vitro: Tielen et al., 1983; Hori et al., 1992). In fact, when the level of postsynaptic depolarization is controlled during tetanic stimuli LTP induction magnitude is equivalent across the lifespan of the F344 rat, indicating that NMDA receptor activation is intact in aged hippocampal area CA1 (Barnes et al., 1996a).

However, long-term maintenance of LTP (L-LTP) is impaired in aged rodents, and this often correlates with deficits in hippocampus-dependent memory (in vivo awake: Barnes, 1979; Barnes and McNaughton, 1980, 1985; in vitro: Bach et al., 1999; reviewed by de Toledo-Morrell et al., 1988). This reduction of LTP maintenance is observed several hours to days after its induction.

The general decline in LTP maintenance observed in old animals is accompanied with a greater susceptibility to induction of LTD and depotentiation in area CA1 of hippocampal slices (Norris et al., 1996; Foster and Norris, 1997). Norris et al. (1996) found that low-frequency stimuli (LFS) that do not elicit lasting changes in synaptic strength in adult rats (e.g., 15-min of 1-Hz stimuli) can induce LTD in old rats. If such LFS is applied to already-potentiated synapses, depotentiation is equivalent in aged and adult rats. However, when spaced bursts of LFS are delivered (30-s of $1-\mathrm{Hz}$ stimuli given at 10-min inter-burst-intervals), synaptic strength in old rats depotentiates more quickly than in adult rats (Norris et al., 1996). Kumar et al. (2007) induced LTD and depotentiation in area CA1 of hippocampal slices from adult and aged rats using a paired LFS protocol; this resulted in equivalent and lasting depression and depotentiation in both age groups. Kumar et al. (2007) concluded that when strong induction stimuli are used the magnitude and stability of LTD is similar in aged and adult rats, and thus the basic synaptic mechanisms required for expression of LTD are intact in aged animals.

\section{AGE-RELATED CHANGES IN LONG-LASTING SYNAPTIC PLASTICITY: POTENTIAL MECHANISMS Signaling, receptors, calcium homeostasis}

Evidence suggests that in advanced age, the activity in some signaling pathways is enhanced, whereas activity in others is diminished. Complex interactions between different patterns of synaptic activity and age-related changes in multiple signaling pathways likely determine the balance between LTP and LTD induction, and maintenance of changes in synaptic strength, in aged animals.

Several definitive molecular changes have been identified in the aged hippocampus that affect synaptic transmission and plasticity. There is a large body of evidence for altered calcium homeostasis in the aged rat hippocampus (e.g., Disterhoft et al., 1996; Hartmann et al., 1996; reviewed by Landfield, 1996; Foster, 2002, 2007). There are two major sources of altered calcium regulation that can affect NMDA receptor-dependent synaptic plasticity: first, the influx of $\mathrm{Ca}^{2+}$ through voltage-dependent calcium channels (VDCCs), such as L-type calcium channels, increases in hippocampal neurons in senescence (Campbell et al., 1996), and an increased density of VDCCs has been identified in CA1 neurons (Thibault and Landfield, 1996). Second, the release of $\mathrm{Ca}^{2+}$ from intracellular calcium stores may be regulated differently in the aged hippocampus (Kumar and Foster, 2004).

The consequences of these age-related changes in calcium handling are far reaching. Calcium action potentials are larger and have increased latency in aged hippocampal neurons (Pitler and Landfield, 1990; Disterhoft et al., 1993). The $\mathrm{Ca}^{2+}$-dependent, $\mathrm{K}^{+}$-mediated afterhyperpolarization is augmented in amplitude and duration in aged hippocampal CA1 cells (Landfield and Pitler, 1984; Kerr et al., 1989; Disterhoft et al., 1993), which can affect induction of LTP (Kumar and Foster, 2004). In fact, a form of LTP that depends on VDCCs but not $\mathrm{NMDA}_{\mathrm{R}}$ activity (Grover and Teyler, $1990,1992,1994$ ) is increased in aged rats, whereas some forms of $\mathrm{NMDA}_{\mathrm{R}}$-dependent LTP are decreased (Shankar et al., 1998). These physiological changes may have important implications for the balance between potentiation and depression in aged animals, as the amplitude and duration of changes in postsynaptic calcium concentrations regulate the strength and direction of plastic changes at synapses (Cummings et al., 1996; Yang et al., 1999; Mizuno et al., 2001; Shouval et al., 2002).

$\mathrm{NMDA}_{\mathrm{R}}$ activity is also reduced in the hippocampus of the aged rat. There are fewer perforant path synapses in the mid-molecular layer of the aged dentate gyrus (Geinisman et al., 1992), and at the remaining synapses, there is a reduced $\mathrm{NMDA}_{\mathrm{R}}$-mediated response (Rao et al., 1994). In area CA1, reduced depolarization in response to stimuli likely results in less $\mathrm{NMDA}_{\mathrm{R}}$ activation and a requirement for stronger patterns of stimuli to induce LTP (Barnes et al., 1997a). Wenk and Barnes (2000) found fewer $\mathrm{NMDA}_{\mathrm{R}}$-binding sites in $\mathrm{CA} 1, \mathrm{CA} 3$, and the subiculum of aged rats, although no differences between age groups were found in the dentate gyrus. Other studies have also found reduced $\mathrm{NMDA}_{\mathrm{R}}$ binding in the aged rat hippocampus (Tamaru et al., 1991; Wenk et al., 1991; Clark et al., 1992; 
but see Shimada et al., 1997; Adams et al., 2001). Magnusson et al. (2002) used semi-quantitative Western blotting to determine that the expression of NR1 and NR2B, but not NR2A, $\mathrm{NMDA}_{\mathrm{R}}$ subunits is decreased in the hippocampus of aged (30-months old) mice as compared to young adults (10-months old). As such, the NR2A/ NR2B ratio may be increased in aged rodents, which could alter induction thresholds such that stronger synaptic activity is required for LTP, and a wider range of low-frequency activity patterns result in LTD (see Yashiro and Philpot, 2008, for a discussion of the interaction between $\mathrm{NMDA}_{\mathrm{R}}$ subunit composition and induction of synaptic plasticity). This agrees with observed age-related changes in LTP/LTD induction. Further studies that conjointly examine electrophysiological properties and receptor expression would be useful to fully understand the physiological consequences of agerelated changes in hippocampal $\mathrm{NMDA}_{\mathrm{R}}$ activity.

\section{Implications for protein synthesis-dependent LTP in senescence}

There is some evidence that signaling pathways that can stimulate new transcription and translation undergo changes with aging. The forms of L-LTP that exhibit age-related reductions in maintenance are often induced by multiple, spaced trains of high-frequency activity; these types of induction protocols also elicit activity of the cAMP pathway and CREB in hippocampal neurons (Frey et al., 1993; Matthies and Reymann, 1993; Nguyen et al., 1994; Blitzer et al., 1995), in which age-related changes have been identified (Godefroy et al., 1989; Luine et al., 1990; Araki et al., 1995; Asanuma et al., 1996; Karege et al., 2001a,b; Monti et al., 2005; Porte et al., 2008). Other signaling pathways, including MAPK, also undergo changes with aging that could affect induction of new protein synthesis (e.g., Davis et al., 2000; Van der Zee, 2004; Williams et al., 2006, 2007).

Relatively few studies have directly examined molecular mechanisms of reduced L-LTP in aged rodents. Bach et al. (1999) examined both E-LTP and L-LTP in area CA1 of hippocampal slices from young (3-month old) and aged (18 month old) mice and found that E-LTP was equivalent between age groups $1 \mathrm{~h}$ after induction. Although initial levels of potentiation were similar between age groups immediately after induction, L-LTP measured $3 \mathrm{~h}$ after induction was reduced in aged mice. Furthermore, spatial memory (measured with the Barnes maze) correlated with 3-h L-LTP within the aged cohort. Upregulation of the cAMP-dependent signaling pathway via application of dopamine D1/D5 receptor agonists attenuated age-related reductions in L-LTP and spatial memory in aged mice, providing further evidence that activity in this pathway is altered in the aged rodent.

Although much research has focused on postsynaptic changes following LTP, there is some evidence that new protein synthesis can be initiated in the presynaptic neuron following LTP induction, and that it has a role in regulating the number of synaptic terminals and the rate of vesicle recycling (Malgaroli et al., 1995; Ryan et al., 1996; Ma et al., 1999; Kelly et al., 2000). Although no agerelated changes have been observed in hippocampal paired-pulse facilitation (Landfield et al., 1978; Barnes, 1979; Deupree et al., 1993), which relies on presynaptic mechanisms, presynaptic protein synthesis may be diminished following LTP induction in aged rats. Kelly et al. (2000) investigated protein synthesis in the entorhinal cortex following potentiation of the perforant pathway in young (4-month old) and old (22-month old) rats. Tetanic stimulation significantly increased protein synthesis in the entorhinal cortex of young, but not aged, rats; this correlated with reduced levels of potentiation in the aged rats $40 \mathrm{~min}$ after potentiation. In particular, expression of synaptophysin and Trk proteins were enhanced in the entorhinal cortex following potentiation in young, but not aged, rats. Even in the absence of tetanic stimuli, protein synthesis was reduced in the entorhinal cortex of aged rats.

Gooney et al. (2004) examined the role of BDNF in potentiation in the young (2- to 4-month old) and aged (20- to 24-month old) rat dentate gyrus by pharmacologically inducing L-LTP using BDNF application. A long-lasting potentiation was observed in both age groups, but the magnitude of potentiation was attenuated in aged rats. Interestingly, ERK phosphorylation in dentate gyrus synaptosomes was enhanced to a greater degree in young than in aged rats, also suggesting that presynaptic mechanisms of LTP change during aging. In light of the critical, but incompletely understood role of BDNF in protein synthesis-dependent L-LTP (Lu et al., 2008), the reduced BDNF-LTP seen in aged rats might indicate defective activity downstream of the BDNF synthesis that is typically observed during LTP.

There are indications that the balance between LTP and LTD induction is shifted in aged rodents. Huang and Kandel (2006) found that a novel form of protein synthesis-dependent LTP could be induced by applying $1 \mathrm{~min}$ of $1-\mathrm{Hz}$ paired-pulse stimulation to area CA1 of hippocampal slices from middle aged and old (6-7-, 12and 18-month old) but not young (6-8 week old) mice. Emetine (an irreversible protein synthesis blocker that prevents the coordinated movement of mRNA through the ribosome) blocked this potentiation more strongly than did rapamycin (an inhibitor of mammalian target of rapamycin (mTOR), which has a role in local protein synthesis), suggesting that local protein synthesis at dendritic sites may have a small role in maintenance of this potentiation. Huang and Kandel also showed that this LTP is mediated by D1/D5 dopamine receptor and protein kinase A activity, which could have roles in eliciting protein synthesis. Interestingly, induction of this 1-Hz LTP in aged rats requires NMDA receptor activity, and its maintenance requires VDCC activity. Considering the known changes in VDCC conductance in aged rodents, it is likely that postsynaptic $\mathrm{Ca}^{2+}$ levels differ between young and old rats following this type of tetanic stimulation, which may be the cause for different LTP induction thresholds between the age groups. Because memory is enhanced by VDCC blockade in aged animals (Deyo et al., 1989; Scriabine et al., 1989; Straube et al., 1990; McMonagle-Strucko and Fanelli, 1993), Huang and Kandel's data suggest that inhibiting forms of plasticity induced by low-frequency stimulation may confer benefits for memory function in the aged.

Like Huang and Kandel, Kumar and Foster (2007) found a shift in induction mechanisms for a long-lasting form of LTD in aged rats. This LTD was induced by application of the group I metabotropic receptor selective agonist $(R, S)$-3,5-dihydroxyphenylglycine (DHPG) and was measured at CA3-CA1 synapses. This LTD was greater in magnitude in aged rats than in young rats 30-min after induction, and relied on protein synthesis only in the aged group. The receptors and signaling cascades required for induction varied between groups: mGluR1 and NMDA receptors, and VDCCs, contributed more to induction in aged rats, whereas protein tyrosine 
phosphatases were crucial for induction in young rats. This study, and that of Huang and Kandel (2006), illustrates that some forms of long-lasting synaptic depression are enhanced in aged animals, and suggests that age-related changes in the activity of signaling cascades affect induction thresholds for synaptic plasticity. Here, protein synthesis is elicited only in aged rats, demonstrating that the mechanisms required for translation still function at some level, but are recruited by different types of stimulation.

Collectively, the evidence thus far suggests that in the aged rodent, the expression of protein synthesis-dependent synaptic strengthening is diminished, whereas that of protein synthesis-dependent synaptic depression is increased. This may result from changes in calcium homeostasis and signaling pathway activity that affect the balance between induction of synaptic potentiation and depression, and recruitment of protein synthesis processes in the aged.

\section{CHANGES IN BEHAVIORALLY INDUCED PLASTICITY DURING AGING}

Although informative, the interpretation of ex vivo studies of synaptic plasticity can be limited because the artificial electrical or chemical stimuli that induce the plasticity are not naturalistic. In vivo studies, however, have confirmed that the ability to modify synaptic transmission does undergo age-related change. In particular, studies of hippocampal place cells in aged rats have illustrated the effects that subtle changes in plasticity mechanisms can have on the function of a cognitive system.

\section{BASIC PLACE FIELD PROPERTIES ARE LARGELY INTACT IN AGING}

Many of the basic properties of hippocampal CA1 neuron place fields are intact in aged rats (reviewed by Rosenzweig and Barnes, 2003). Mean and maximum firing rates, inter-spike-interval distributions, and spike characteristics (e.g., amplitude, width) are similar between age groups (Barnes et al., 1983; Shen et al., 1997). When aged rats initially enter an environment, place fields form normally and are the same size as those seen in young rats (Shen et al. 1997). Although there is a small reduction in overall theta frequency during maze running in the aged hippocampus, place fields show normal phase precession in relation to the theta rhythm (Shen et al., 1997). For CA3, on the other hand, although place field size does not change with age, the mean firing rates of these cells are increased (Wilson et al., 2005).

\section{PLACE FIELD EXPANSION PLASTICITY IS DIMINISHED IN AGED RATS}

Place fields expand when young rats repeatedly traverse the same linear path, and place field centers move slightly "backwards" along the path (Mehta et al., 1997). In order to explain why this might occur, consider that while a rat is running along a given trajectory, a number of place fields become active in sequence; that is, firing of one cell will repeatedly precede the firing of the next. Synaptic connections between these cells may undergo LTP-like, or Hebbian, plasticity mechanisms such that their connections are strengthened. Following this synaptic enhancement, firing of the first cell will cause firing of the second cell earlier in temporal/spatial order than the original activity, resulting in backwards expansion of the second place field (see Rosenzweig and Barnes, 2003, for more details, and Mehta et al., 2000, for a model of CA3-CA1 plasticity that gives rise to these place field properties).
This place field expansion plasticity may function to facilitate sequence and path learning (Levy, 1989; Abbott and Blum, 1996; Blum and Abbott, 1996; Redish and Touretzky, 1998; Lisman and Redish, 2009), as the activation of one cell could come to propagate activity of the rest of the cells in a sequence. More recently, the discovery of reverse replay of place field sequences during sharp wave activity while on a linear maze (Foster and Wilson, 2006; Csicsvari et al., 2007) has prompted speculation that place cells may form bidirectional connections. Furthermore, the observation of "forward sweeps" of sequential activity at a choice point in a maze in area CA3 (Johnson and Redish, 2007) has been suggested as evidence that such propagated activity may be used to guide future behavior (Lisman and Redish, 2009).

Place field expansion is reduced in aged rats such that place fields do not expand to the extent that occurs in young rats through up to 15 traversals of a rectangular track (Shen et al., 1997). Although place field sizes were similar between young and old rats on the first lap of the maze, indicating that they form normally, field sizes were larger in young rats during laps 5, 10, and 15 . These data provide an explanation for reduced field size in aged rats that was calculated over many traversals of the place fields in earlier studies (Markus et al., 1994; Mizumori et al., 1996). As CA1 place field expansion plasticity does not persist to subsequent sessions of maze running a day later in a familiar environment (Mehta et al., 1997; Lee et al., 2004), it likely reflects short-term plasticity processes in the intact animal. As such, it is not possible to draw conclusions restricted to mechanisms of long-term plasticity from studies of place field expansion in aged rats, but this finding is one of few examples of age deficits in a plasticity-dependent mechanism that has been recorded from an awake, behaving animal during naturalistic behavior. The reduction of place field expansion in aged rats may have consequences for learning sequences and guidance of future spatial behaviors.

\section{ALTERED NMDA ${ }_{R}$ ACTIVITY IN AGED ANIMALS AFFECTS PLACE FIELD PROPERTIES}

Place field expansion depends on $\mathrm{NMDA}_{\mathrm{R}}$ activity (Ekstrom et al., 2001), further suggesting that LTP-like processes are involved in its expression. Reduced $\mathrm{NMDA}_{\mathrm{R}}$ activity in the hippocampus of the aged rat possibly explains the observed age-related decline in place field expansion. With these age-related changes in $\mathrm{NMDA}_{\mathrm{R}}$ activity in mind, Burke et al. (2008) designed a study in which an attempt was made to pharmacologically restore place field expansion in aged rats. Memantine, a low-affinity, non-competitive $\mathrm{NMDA}_{\mathrm{R}}$ antagonist, blocks the open pore of the receptor (Parsons et al., 1995). This drug was selected for the study because it enhances spatial memory in the Morris water maze and LTP maintenance in adult rats (Barnes et al., 1996b). Burke et al. (2008) found that memantine, but not ampakine CX516, augmented place field expansion in hippocampal area CA1 of 24- to 30-month old F344 rats. It is interesting that treatment with the competitive $\mathrm{NMDA}_{\mathrm{R}}$ antagonist CPP prevents place field expansion (Ekstrom et al., 2001), whereas memantine facilitates this in aged rats. It has been hypothesized that memantine's unique chemical properties (fast offset kinetics and strong voltage dependency) act to restore glutamatergic homeostasis, rather than to block NMDA $_{\mathrm{R}}$ activity (Parsons et al., 2007). Thus, memantine may increase the signal to noise ratio of $\mathrm{NMDA}_{\mathrm{R}}$-dependent signaling to restore plasticity mechanisms in aged rats. 


\section{LONG-TERM PLACE FIELD STABILIZATION}

Place fields form immediately when animals enter an environment for the first time (Bostock et al., 1991; Wilson and McNaughton, 1993) and can remain stable for months (Thompson and Best, 1990). Even when $\mathrm{NMDA}_{\mathrm{R}}$ activity (and presumably LTP) is blocked pharmacologically with CPP, fields can remain stable for several hours. However, long-term stabilization of this new "map" in CA1 requires $\mathrm{NMDA}_{\mathrm{R}}$ activity during exploration (Kentros et al., 1998). If CPP is applied during initial encoding of the map in adult animals, later retrieval of the map is not successful, and this is due to impaired plasticity mechanisms. Agnihotri et al. (2004) further demonstrated that mechanisms required for L-LTP are also necessary for long-term stabilization of new place fields by blocking protein synthesis with anisomycin during encoding; protein synthesis is required for stabilization of a new hippocampal map that lasts $6 \mathrm{~h}$ or more in young mice. Considering the age-related changes observed in protein synthesis and L-LTP, it can be hypothesized that place fields may be less stable in the long-term in aged rodents. Correspondingly, Yan et al. (2003) have demonstrated reduced stability of CA1 place fields $24 \mathrm{~h}$ after encoding in aged mice.

Interestingly, old rats sometimes express a failure to retrieve previously expressed maps, similar to what occurs when NMDA receptors are blocked during place field encoding. Barnes et al. (1997b) recorded CA1 place cell activity in aged rats during repeated visits to a familiar environment. On about $30 \%$ of the visits, the aged rats expressed a different hippocampal map than during their previous visit. Most or all cells completely changed their place-specific firing pattern between these visits. Cells never changed their firing fields during a visit; the only time "remapping" was observed was upon re-entry to the environment after an absence. These findings in aged rats are strikingly reflective of the instability of CA1 place fields seen in CPP-treated adult rats (Kentros et al., 1998), suggesting that impaired plasticity mechanisms in aged rats contribute to this instability of place representations.

\section{CHANGES IN SPATIAL REPRESENTATIONS}

Although place representations in area CA1 are less stable in aged than in young rats when an environment remains consistent (Barnes et al., 1997b), this is not the case in all regions of the hippocampus. In fact, areas CA1 and CA3 have distinct roles in the processing of spatial information (Lee et al., 2004; Leutgeb et al., 2004, 2006; Vazdarjanova and Guzowski, 2004; reviewed by Leutgeb and Leutgeb, 2007). These hippocampal subregions may have dissociable roles in pattern completion and pattern separation (described by Marr, 1971; McNaughton and Morris, 1987). The function of area CA3 appears to be influenced differently by changes in hippocampal plasticity during aging than that of area CA1. Whereas place representations in young CA3 change when a rat is moved from a familiar to a novel environment, place fields in aged CA3 tend to generalize between environments such that they express similar fields in both (Wilson et al., 2005).

These age differences in CA3 processing may originate with its inputs from granule cells; it is believed that sparse encoding in the dentate gyrus contributes to the coded orthogonalization of spatial information. The dentate gyrus is particularly vulnerable to the effects of aging (Small et al., 2002, 2004), and as such, the orthogonalization of spatial inputs may be less effective in the aged rodent.
Another possible explanation is that mossy fiber LTP is impaired in aged rodents, allowing autoassociative processing in CA3 to promote the stabilization of already-formed representations in the relative absence of consistent pattern separation input from granule cells.

Weakened synaptic plasticity in the aged hippocampus may also result in less binding of landmarks and cues via LTP-like processes to the hippocampal map, as suggested by models in which the map is initially based on self-motion (e.g., McNaughton et al., 1996; Touretzky and Redish, 1996). Rosenzweig et al. (2003) found that when rats begin their journeys along a linear track at different starting points, place fields in area CA1 are initially aligned to the starting position, representing dominance of self-motion input. During the rat's journey to the end of the track, these place fields realigned with reference to their position in the room, indicating a dominant influence of visual input. In aged rats, this realignment to visual input signals was delayed with respect to that observed in young rats. This is evidence for an increased dependence on self-motion input in aged rats, which may result from weakened plasticity and less binding of cue information to the hippocampal map.

\section{REACTIVATION}

The hippocampus may participate in consolidation of memory to long-term storage sites in the neocortex (e.g., Scoville and Milner, 1957; Winocur, 1990; Zola-Morgan and Squire, 1990). Although the exact nature of hippocampus-neocortical interactions necessary for this storage is not well understood, it has been hypothesized that the hippocampus "reactivates" activity patterns during offline periods (i.e., rest or sleep) when external inputs are not being processed (e.g., Marr, 1971; reviewed by McNaughton and Morris, 1987; McNaughton et al., 2003). It has been shown that during quiet resting, for at least 30-min following behavior (such as running on a maze), ensembles of hippocampal neurons express patterns of neural firing correlations consistent with those seen during behavior (Pavlides and Winson, 1989; Wilson and McNaughton, 1994; Kudrimoti et al., 1999).

Because of the hippocampal memory and plasticity impairments seen in aged rats, it was hypothesized that reactivation may be impaired in these animals because it requires long-term persistence of activity patterns within hippocampal networks. Reactivation does occur in the hippocampus of aged rats (Gerrard et al., 2001); however, when the temporal order of activity patterns was compared between behavior and rest using a method of analysis that is very sensitive to the sequence in which neurons fire action potentials, it was shown that aged rats show less preservation of the sequence of firing than do young rats (Gerrard et al., 2008). When levels of sequence reactivation were compared to performance in the Morris water maze, it was found that rats with cell pairs showing the strongest tendency to fire in the same sequence during rest as during behavior also expressed the highest spatial memory scores, suggesting that deficient sequence reactivation contributes to memory impairments in aged rats.

\section{CONCLUSIONS AND FUTURE DIRECTIONS}

There is considerable evidence that during aging, there are changes in the regulation of protein synthesis. Both transcription and translation are affected; in fact, following artificial or behavioral stimulation, some proteins are expressed to a greater degree in the hippocampi 
of aged rodents compared to young or adult rodents, and others are expressed less. Similarly, when protein synthesis levels are examined in aged rodents, decreased synthesis is observed in some, but not all, brain regions. These observations converge to show that the whole brain protein synthesis decrease observed in senescence, in fact, represents numerous and complex changes in transcription and translation that can differ from region to region.

Some of these age-related changes in protein synthesis mechanisms have been studied in conjunction with long-term memory. This approach can provide direction for the development of pharmaceutical interventions to alleviate the memory loss that accompanies normal aging. Memantine, for example, is used to treat cognitive impairment and mild to moderate dementia associated with Alzheimer's disease (Rogawski and Wenk, 2003; Peskind et al., 2006). Its effects in restoring place field expansion (Burke et al., 2008) and in enhancing spatial memory and hippocampal LTP (Barnes et al., 1996b) in aged rats suggest that it may also reduce memory loss in normal aging by restoring some forms of synaptic plasticity. Recruitment of the cAMP signaling pathway and pCREB activity is another potential approach. Several studies have already indicated that treatment with dopamine, which interacts with this pathway, facilitates motor memory and cognitive skill learning in the elderly (Peretti et al., 2004; Flöel et al., 2005, 2008) and working memory in aged monkeys (Castner and Goldman-Rakic, 2004), in addition to enhancing hippocampal LTP in aged rats (Bach et al., 1999).

Another potential avenue for pharmaceutical development is protein kinase $\mathrm{M}$ zeta $(\mathrm{PKM} \zeta)$, a molecule that is necessary and sufficient for maintenance of LTP in hippocampal area CA1 (Ling et al., 2002). Inhibition of PKM $\zeta$ with a cell-permeable synthetic peptide that selectively inhibits PKM (ZIP) can "erase" recently encoded memories (Pastalkova et al., 2006; Shema et al., 2007). Preliminary studies have indicated that increasing PKM $\zeta$ activity can enhance memory in aged rats, thus, manipulation of PKM $\zeta$ activity may prove fruitful in reducing age-related memory decline (see Schneider et al., 2010 in this special topic for details).

It has recently become evident that epigenetic mechanisms may contribute to age-related changes in memory and synaptic plasticity (see review by Penner et al., 2010b). Penner et al. (2010a) have

\section{REFERENCES}

Abbott, L. F., and Blum, K. I. (1996). Functional significance of long-term potentiation for sequence learning and prediction. Cereb. Cortex 6, 406-416.

Abraham, W.C., Dragunow, M., and Tate, W. P. (1991). The role of immediate early genes in the stabilization of longterm potentiation. Mol. Neurobiol. 5, 297-314.

Abraham, W. C., and Williams, J. M. (2003). Properties and mechanisms of LTP maintenance. Neuroscientist 9, 463-474.

Abraham, W. C., and Williams, J. M. (2008). LTP maintenance and its protein synthesis-dependence. Neurobiol. Learn. Mem. 89, 260-268.

Adams, M. M., Smith, T. D., Moga, D., Gallagher, M., Wang, Y., Wolfe, B. B.,

found altered methylation of the Arc gene in aged rats. There is also evidence that pharmacological intervention to alter the activity of histone acetyltransferases (HATs), co-activators that have a role in regulating CRE-dependent transcription by CREB, can enhance memory and synaptic plasticity in normal animals and in models of neurodegeneration (Fischer et al., 2007; Lattal et al., 2007; Vecsey et al., 2007). Histone deacetylase (HDAC) counters the actions of HATs, and thus HDAC inhibitors can serve to enhance transcriptional efficacy. Clinical studies will be necessary to determine whether HDAC inhibitors are effective in reversing memory decline in advanced age.

Estrogen treatment has also been examined as a potential memory enhancer especially for the middle aged, as it improves spatial memory, reduces propensity for synaptic depression, and may facilitate hippocampal transcription in female rats (Foster et al., 2003; Foy et al., 2008; Aenlle et al., 2009; reviewed by Foster, 2005). Although there is limited evidence for the efficacy of clinical estrogen treatment for age-related memory loss (perhaps because of study design), there is potential for estrogen treatment in mid-life to provide mnemonic benefits later in life (reviewed by Henderson, 2009).

Developing a full understanding of changes in transcription and translation during aging will provide deeper insight into which pharmaceutical interventions will be most effective in preventing memory loss. The interactions of many factors in addition to protein synthesis are thought to determine susceptibility to age-related cognitive decline, such as oxidative stress, epigenetic modification of the genome, and age-related changes in neuromodulation and growth factors. Because the composition of neuronal proteins ultimately dictates synaptic function, it might be most effective for future studies to focus on determining how all biological correlates of aging affect the synthesis and activity of proteins known to have roles in long-lasting forms of synaptic plasticity and memory.

\section{ACKNOWLEDGMENTS}

Supported by the McKnight Brain Research Foundation and AG012609.

Rapp, P.R., and Morrison, J.H. (2001). Hippocampal dependent learning ability correlates with N-methyl-Daspartate (NMDA) receptor levels in CA3 neurons of young and aged rats. J. Comp. Neurol. 432, 230-243.

Aenlle, K. K., Kumar, A., Cui, L., Jackson, T. C., and Foster, T. C. (2009). Estrogen effects on cognition and hippocampal transcription in middle-aged mice. Neurobiol. Aging 30, 932-945.

Agnihotri, N. T., Hawkins, R. D., Kandel, E. R., and Kentros, C. (2004). The long-term stability of new hippocampal place fields requires new protein synthesis. Proc. Natl. Acad. Sci. U.S.A. 101, 3656-3661.

Alberini, C.M. (2008). The role of protein synthesis during the labile phases of memory: revisiting the skepticism. Neurobiol. Learn. Mem. 89, 234-246.
Anagnostaras, S. G., Maren, S., and Fanselow, M. S. (1999). Temporally graded retrograde amnesia of contextual fear after hippocampal damage in rats: within-subjects examination. J. Neurosci. 19, 1106-1114.

Applegate, M. D., and Landfield, P. W. (1988). Synaptic vesicle redistribution during hippocampal frequency potentiation and depression in young and aged rats. J. Neurosci. 8, 1096-1111.

Araki, T., Kato, H., Fujiwara, T., and Itoyama, Y. (1995). Age-related changes in bindings of second messengers in the rat brain. Brain Res. 704, 227-232.

Asanuma, M., Nishibayashi, S., Iwata, E., Kondo, Y., Nakanishi, T., Vargas, M. G., and Ogawa, N. (1996). Alterations of cAMP response element-binding activity in the aged rat brain in response to administration of rolipram, a cAMP-specific phosphodiesterase inhibitor. Brain Res. Mol. Brain Res. 41, 210-215.

Athos, J., Impey, S., Pineda, V.V., Chen, X., and Storm, D. R. (2002). Hippocampal CRE-mediated gene expression is required for contextual memory formation. Nat. Neurosci. 5, 1119-1120.

Bach, M.E., Barad, M., Son, H., Zhuo, M., Lu, Y. F., Shih, R., Mansuy, I., Hawkins, R. D., and Kandel, E. R. (1999). Agerelated defects in spatial memory are correlated with defects in the late phase of hippocampal long-term potentiation in vitro and are attenuated by drugs that enhance the CAMP signaling pathway. Proc. Natl. Acad. Sci. U.S.A. 96, 5280-5285.

Bailey, C. H., Bartsch, D., and Kandel, E. R. (1996). Toward a molecular 
definition of long-term memory storage. Proc. Natl. Acad. Sci. U.S.A. 93, 13445-13452.

Barnes, C. A. (1979). Memory deficits associated with senescence: a neurophysiological and behavioral study in the rat. J. Comp. Physiol. Psychol. 93, 74-104.

Barnes, C. A., and McNaughton, B. L. (1980). "Spatial memory and hippocampal synaptic plasticity in middle-aged and senescent rats," in Psychobiology of Aging: Problems and Perspectives, ed. D. Stein (New York, NY: Elsevier), 253-272.

Barnes, C. A., and McNaughton, B. L. (1985). An age comparison of the rates of acquisition and forgetting of spatial information in relation to long-term enhancement of hippocampal synapses. Behav. Neurosci. 99, 1040-1048.

Barnes, C. A., McNaughton, B. L., and O'Keefe, J. (1983). Loss of place specificity in hippocampal complex spike cells of senescent rat. Neurobiol. Aging 4, 113-119.

Barnes, C. A., Nadel, L., and Honig, W. K. (1980). Spatial memory deficit in senescent rats. Can. J. Psychol. 34, 29-39.

Barnes, C. A., Rao, G., and McNaughton, B. L. (1996a). Functional integrity of NMDA-dependent LTP induction mechanisms across the lifespan of F-344 rats. Learn. Mem. 3, 124-137.

Barnes, C. A., Danysz, W., and Parsons, C. G. (1996b). Effects of the uncompetitive NMDA receptor antagonist memantine on hippocampal long-term potentiation, short-term exploratory modulation and spatial memory in awake, freely moving rats. Eur. J. Neurosci. 8, 565-571.

Barnes, C. A., Rao, G., and Shen, J. (1997a). Age-related decrease in the N-methylD-aspartateR-mediated excitatory postsynaptic potential in hippocampal region CA1. Neurobiol. Aging 18, 445-452.

Barnes, C. A., Suster, M. S., Shen, J. and McNaughton, B. L. (1997b). Multistability of cognitive maps in the hippocampus of old rats. Nature 388, 272-275.

Bishop, N. A., Lu, T., and Yankner, B. A. (2010). Neural mechanisms of ageing and cognitive decline. Nature 464, 529-535.

Bito, H., Deisseroth, K., and Tsien, R. W. (1996). CREB phosphorylation and dephosphorylation: a $\mathrm{Ca}(2+)$ - and stimulus duration-dependent switch for hippocampal gene expression. Cell 87, 1203-1214.

Blalock, E. M., Chen, K., Sharrow, K., Herman, J. P., Porter, N. M., Foster, T. C., and Landfield, P. W. (2003). Gene microarrays in hippocampal aging: statistical profiling identifies novel processes correlated with cognitive impairment. J. Neurosci. 23, 3807-3819.

Bliss, T. V., and Lomo, T. (1973). Longlasting potentiation of synaptic transmission in the dentate area of the anaesthetized rabbit following stimulation of the perforant path. J. Physiol. 232, 331-356.

Blitzer, R. D., Wong, T., Nouranifar, R., Iyengar, R., and Landau, E. M. (1995). Postsynaptic cAMP pathway gates early LTP in hippocampal CA1 region. Neuron 15, 1403-1414.

Blum, K. I., and Abbott, L. F. (1996). A model of spatial map formation in the hippocampus of the rat. Neural. Comput. 8, 85-93.

Bostock, E., Muller, R. U., and Kubie, J. L. (1991). Experience-dependent modifications of hippocampal place cell firing. Hippocampus 1, 193-205.

Bourtchouladze, R., Abel, T., Berman, N., Gordon, R., Lapidus, K., and Kandel, E. R. (1998). Different training procedures recruit either one or two critical periods for contextual memory consolidation, each of which requires protein synthesis and PKA. Learn. Mem. 5, 365-374.

Brightwell, J.J., Smith, C.A., Countryman, R. A., Neve, R. L., and Colombo, P. J. (2005). Hippocampal overexpression of mutant creb blocks long-term, but not short-term memory for a socially transmitted food preference. Learn. Mem. 12, 12-17.

Burke, S. N., and Barnes, C. A. (2006). Neural plasticity in the ageing brain. Nat. Rev. Neurosci. 7, 30-40.

Burke, S. N., Maurer, A. P., Yang, Z., Navratilova, Z., and Barnes, C. A. (2008). Glutamate receptor-mediated restoration of experience-dependent place field expansion plasticity in aged rats. Behav. Neurosci. 122, 535-548.

Campbell, L. W., Hao, S. Y., Thibault, O., Blalock, E. M., and Landfield, P. W. (1996). Aging changes in voltagegated calcium currents in hippocampal CA1 neurons. J. Neurosci. 16, 6286-6295.

Castner, S. A., and Goldman-Rakic, P. S. (2004). Enhancement of working memory in aged monkeys by a sensitizing regimen of dopamine D1 receptor stimulation. J. Neurosci. 24, 1446-1450.

Chang, P. L., Isaacs, K. R., and Greenough, W. T. (1991). Synapse formation occurs in association with the induction of long-term potentiation in twoyear-old rat hippocampus in vitro. Neurobiol. Aging 12, 517-522.

Chung, Y.H., Kim, E. J., Shin, C. M., Joo, K. M., Kim, M. J., Woo, H.W., and Cha, C. I. (2002). Age-related changes in CREB binding protein immunoreactivity in the cerebral cortex and hippocampus of rats. Brain Res. 956, 312-318.

Clark, A. S., Magnusson, K. R., and Cotman, C. W. (1992). In vitro autoradiography of hippocampal excitatory amino acid binding in aged Fischer 344 rats: relationship to performance on the Morris water maze. Behav. Neurosci. 106, 324-335.

Cole, A. J., Saffen, D. W., Baraban, J. M., and Worley, P.F. (1989). Rapid increase of an immediate early gene messenger RNA in hippocampal neurons by synaptic NMDA receptor activation. Nature 340, 474-476.

Countryman, R.A., and Gold,P.E. (2007) Rapid forgetting of social transmission of food preferences in aged rats: relationship to hippocampal CREB activation. Learn. Mem. 14, 350-358.

Csicsvari, J., O'Neill, J., Allen, K., and Senior, T. (2007). Place-selective firing contributes to the reverse-order reactivation of CAl pyramidal cells during sharp waves in open-field exploration. Eur. J. Neurosci. 26, 704-716.

Cummings, J.A., Mulkey, R. M., Nicoll, R. A., and Malenka, R. C. (1996). Ca2+ signaling requirements for long-term depression in the hippocampus. Neuron 16, 825-833.

Davis, H. P., Rosenzweig, M. R., Kinkade, P. T., and Bennett, E. L. (1981). Effects of anisomycin on retention of the passive-avoidance habit as a function of age. Exp. Aging Res. 7, 33-44.

Davis, H. P., and Squire, L. R. (1984). Protein synthesis and memory: a review. Psychol. Bull. 96, 518-559.

Davis, S., Vanhoutte, P., Pages, C., Caboche, J., and Laroche, S. (2000). The MAPK/ ERK cascade targets both Elk-1 and cAMP response element-binding protein to control long-term potentiation-dependent gene expression in the dentate gyrus in vivo. J. Neurosci. 20, 4563-4572.

Deisseroth, K., Bito, H., and Tsien, R. W. (1996). Signaling from synapse to nucleus: postsynaptic CREB phosphorylation during multiple forms of hippocampal synaptic plasticity. Neuron 16, 89-101.

Desjardins, S., Mayo, W., Vallée, M. Hancock, D., Le Moal, M., Simon, H., and Abrous, D. N. (1997). Effect of aging on the basal expression of c-Fos, c-Jun, and Egr-1 proteins in the hippocampus. Neurobiol. Aging $18,37-44$.

de Toledo-Morrell, L., Geinisman, Y., and Morrell, F. (1988). Age-dependent alterations in hippocampal synaptic plasticity: relation to memory disorders. Neurobiol. Aging 9, 581-590.

Deupree, D. L., Bradley, J., and Turner, D. A. (1993). Age-related alterations in potentiation in the $\mathrm{CA} 1$ region in $\mathrm{F} 344$ rats. Neurobiol. Aging 14, 249-258.
Deupree, D. L., Turner, D. A., and Watters, C. L. (1991). Spatial performance correlates with in vitro potentiation in young and aged Fischer 344 rats. Brain Res. 554, 1-9.

Deyo, R. A., Straube, K. T., and Disterhoft, J. F. (1989). Nimodipine facilitates associative learning in aging rabbits. Science 243, 809-811.

Diana, G., Domenici, M. R., Loizzo, A., Scotti de Carolis, A., and Sagratella, S. (1994a). Age and strain differences in rat place learning and hippocampal dentate gyrus frequency-potentiation. Neurosci. Lett. 171, 113-116.

Diana, G., Scotti de Carolis, A., Frank, C., Domenici, M. R., and Sagratella, S. (1994b). Selective reduction of hippocampal dentate frequency potentiation in aged rats with impaired place learning. Brain Res. Bull. 35, 107-111.

Diana, G., Domenici, M. R., Scotti de Carolis, A., Loizzo, A., and Sagratella, S. (1995). Reduced hippocampal CA1 $\mathrm{Ca}(2+)$-induced long-term potentiation is associated with age-dependent impairment of spatial learning. Brain Res. 686, 107-110.

Disterhoft, J.F., Moyer, J., Thompson, L. T., and Kowalska, M. (1993). Functional aspects of calcium-channel modulation. Clin. Neuropharmacol. 16(Suppl. 1), S12-S24.

Disterhoft, J. F., Thompson, L. T., Moyer, J., and Mogul, D. J. (1996). Calciumdependent afterhyperpolarization and learning in young and aging hippocampus. Life Sci. 59, 413-420.

Dragunow,M.,Abraham, W.C., Goulding, M., Mason, S.E., Robertson, H.A., and Faull, R. L. (1989). Long-term potentiation and the induction of $\mathrm{c}$-fos mRNA and proteins in the dentate gyrus of unanesthetized rats. Neurosci. Lett. 101, 274-280.

Dwyer, B. E., Fando, J. L., and Wasterlain, C. G. (1980). Rat brain protein synthesis declines during postdevelopmental aging. J. Neurochem. 35 , 746-749.

Ekstrom, A. D., Meltzer, J., McNaughton, B. L., and Barnes, C. A. (2001). NMDA receptor antagonism blocks experience-dependent expansion of hippocampal "place fields". Neuron 31, 631-638.

Ekstrom, R., Liu, D. S., and Richardson, A. (1980). Changes in brain protein synthesis during the life span of male Fischer rats. Gerontology 26, 121-128.

Essman, W. B. (1982). Aging-related changes in retrograde amnesia for mice. Gerontology 28, 303-313.

Fando, J. L., Salinas, M., and Wasterlain, C. G. (1980). Age-dependent changes in brain protein synthesis in the rat. Neurochem. Res. 5, 373-383. 
Filion, A. M., and Laughrea, M. (1985). "Translation fidelity in the brain, liver, and hippocampus of the aging Fischer 344 rat," in Molecular Biology of Aging: Gene Stability and Gene Expression, eds R. S. Sohal, L. S. Birnbaum, and R. G. Cutler (New York: Raven Press), 257-261.

Finkbiner, R. G., and Woodruff-Pak, D. S. (1991). Classical eyeblink conditioning in adulthood: effects of age and interstimulus interval on acquisition in the trace paradigm. Psychol. Aging 6, 109-117.

Fischer, A., Sananbenesi, F., Wang, X., Dobbin, M., and Tsai, L. (2007). Recovery of learning and memory is associated with chromatin remodelling. Nature 447, 178-182.

Flexner, J. B., Flexner, L. B., and Stellar, E. (1963). Memory in mice as affected by intracerebral puromycin. Science 141, 57-59.

Flexner, J. B., Flexner, L. B., Stellar, E., de la Haba, G., and Roberts, R. B. (1962). Inhibition of protein synthesis in brain and learning and memory following puromycin. J. Neurochem. 9, 595-605.

Flexner, L. B., Flexner, J. B., and Roberts, R. B. (1967). Memory in mice analyzed with antibiotics. Antibiotics are useful to study stages of memory and to indicate molecular events which sustain memory. Science 155, 1377-1383.

Flöel, A., Breitenstein, C., Hummel, F., Celnik, P., Gingert, C., Sawaki, L., Knecht, S., and Cohen, L. G. (2005). Dopaminergic influences on formation of a motor memory. Ann. Neurol. 58, 121-130.

Flöel,A., Garraux, G., Xu, B., Breitenstein, C., Knecht, S., Herscovitch, P., and Cohen, L. G. (2008). Levodopa increases memory encoding and dopamine release in the striatum in the elderly. Neurobiol. Aging 29, 267-279.

Fonseca, R., Nägerl, U.V., and Bonhoeffer, T. (2006a). Neuronal activity determines the protein synthesis dependence of long-term potentiation. Nat. Neurosci. 9, 478-480.

Fonseca, R., Vabulas, R. M., Hartl, F. U., Bonhoeffer, T., and Nägerl, U. V. (2006b).A balance of protein synthesis and proteasome-dependent degradation determines the maintenance of LTP. Neuron 52, 239-245.

Foster, D. J., and Wilson, M. A. (2006). Reverse replay of behavioural sequences in hippocampal place cells during the awake state. Nature 440, 680-683.

Foster, T. C. (1999). Involvement of hippocampal synaptic plasticity in agerelated memory decline. Brain Res. Brain Res. Rev. 30, 236-249.

Foster, T. C. (2002). Regulation of synaptic plasticity in memory and memory decline with aging. Prog. Brain Res. 138, 283-303.

Foster, T. C. (2005). Interaction of rapid signal transduction cascades and gene expression in mediating estrogen effects on memory over the life span. Front. Neuroendocrinol. 26, 51-64.

Foster, T.C. (2007). Calcium homeostasis and modulation of synaptic plasticity in the aged brain. Aging Cell 6, 319-325.

Foster, T. C., and Norris, C. M. (1997). Age-associated changes in $\mathrm{Ca}(2+)$ dependent processes: relation to hippocampal synaptic plasticity. Hippocampus 7, 602-612.

Foster, T. C., Sharrow, K. M., Kumar, A., and Masse, J. (2003). Interaction of age and chronic estradiol replacement on memory and markers of brain aging. Neurobiol. Aging 24, 839-852.

Foy, M. R., Baudry, M., Foy, J. G., and Thompson, R. F. (2008). 17betaestradiol modifies stress-induced and age-related changes in hippocampal synaptic plasticity. Behav. Neurosci. 122, 301-309.

Frankland, P. W., Josselyn, S. A., Anagnostaras, S. G., Kogan, J. H., Takahashi, E., and Silva, A. J. (2004). Consolidation of CS and US representations in associative fear conditioning. Hippocampus 14, 557-569.

Frey, U., Frey, S., Schollmeier, F., and Krug, M. (1996). Influence of actinomycin $D$, a RNA synthesis inhibitor, on longterm potentiation in rat hippocampal neurons in vivo and in vitro. J. Physiol. 490(Pt 3), 703-711.

Frey, U., Huang, Y. Y., and Kandel, E. R. (1993). Effects of cAMP simulate a late stage of LTP in hippocampal CA1 neurons. Science 260, 1661-1664.

Frey, U., Krug, M., Reymann, K. G., and Matthies, H. (1988). Anisomycin, an inhibitor of protein synthesis, blocks late phases of LTP phenomena in the hippocampal CA1 region in vitro. Brain Res. 452, 57-65.

Gage, F. H., Dunnett, S. B., and Björklund, A. (1984). Spatial learning and motor deficits in aged rats. Neurobiol. Aging 5, 43-48.

Geinisman, Y., Bondareff, W., and Dodge, J. T. (1977). Partial deafferentation of neurons in the dentate gyrus of the senescent rat. Brain Res. 134, 541-545.

Geinisman, Y., Bondareff, W., and Dodge, J. T. (1978). Dendritic atrophy in the dentate gyrus of the senescent rat. Am. J. Anat. 152, 321-329.

Geinisman, Y., deToledo-Morrell, L., Morrell, F., Persina, I. S., and Rossi, M. (1992). Age-related loss of axospinous synapses formed by two afferent systems in the rat dentate gyrus as revealed by the unbiased stereological dissector technique. Hippocampus 2, 437-444.

Gerrard, J.L., Burke, S. N., McNaughton, B. L., and Barnes, C.A. (2008). Sequence reactivation in the hippocampus is impaired in aged rats. J. Neurosci. 28, 7883-7890.

Gerrard,J.L., Kudrimoti,H.,McNaughton, B. L., and Barnes, C. A. (2001) Reactivation of hippocampal ensemble activity patterns in the aging rat. Behav. Neurosci. 115, 1180-1192.

Godefroy, F., Bassant, M.H., Weil-Fugazza, J., and Lamour, Y. (1989). Age-related changes in dopaminergic and serotonergic indices in the rat forebrain. Neurobiol. Aging 10, 187-190.

Gonzalez, G. A., and Montminy, M. R. (1989). Cyclic AMP stimulates somatostatin gene transcription by phosphorylation of CREB at serine 133 Cell 59, 675-680.

Gooney, M., Messaoudi, E., Maher, F. O. Bramham, C. R., Lynch, M. A. (2004). BDNF-induced LTP in dentate gyrus is impaired with age: analysis of changes in cell signaling events. Neurobiol. Aging 25, 1323-1331.

Grimm, R., Schicknick, H., Riede, I. Gundelfinger, E. D., Herdegen, T., Zuschratter, W., and Tischmeyer, W. (1997). Suppression of c-fos induction in rat brain impairs retention of a brightness discrimination reaction. Learn. Mem. 3, 402-413.

Grover, L. M., and Teyler, T. J. (1990). Two components of long-term potentiation induced by different patterns of afferent activation. Nature 347, 477-479.

Grover, L. M., and Teyler, T. J. (1992). $\mathrm{N}$-methyl-D-aspartate receptorindependent long-term potentiation in area CA1 of rat hippocampus: input-specific induction and preclusion in a non-tetanized pathway. Neuroscience 49, 7-11.

Grover, L. M., and Teyler, T. J. (1994). Activation of NMDA receptors in hippocampal area CA1 by low and high frequency orthodromic stimulation and their contribution to induction of long-term potentiation. Synapse 16, 66-75.

Gruart,A., López-Ramos, J.C., Muñoz, M D., and Delgado-García, J. M. (2008). Aged wild-type and APP, PS1, and APP+PS1 mice present similar deficits in associative learning and synaptic plasticity independent of amyloid load. Neurobiol. Dis. 30, 439-450.

Gruart, A., Muñoz, M. D., and DelgadoGarcía, J. M. (2006). Involvement of the CA3-CA1 synapse in the acquisition of associative learning in behaving mice. J. Neurosci. 26, 1077-1087.

Guzowski, J. F. (2002). Insights into immediate-early gene function in hippocampal memory consolida- tion using antisense oligonucleotide and fluorescent imaging approaches. Hippocampus 12, 86-104.

Guzowski, J. F., Lyford, G. L., Stevenson, G. D., Houston, F. P., McGaugh, J. L., Worley, P. F., and Barnes, C. A. (2000). Inhibition of activity-dependent arc protein expression in the rat hippocampus impairs the maintenance of long-term potentiation and the consolidation of long-term memory. J. Neurosci. 20, 3993-4001.

Guzowski, J. F., and McGaugh, J. L. (1997). Antisense oligodeoxynucleotidemediated disruption of hippocampal cAMP response element binding protein levels impairs consolidation of memory for water maze training. Proc. Natl. Acad. Sci. U.S.A. 94, 2693-2698.

Guzowski, J. F., McNaughton, B. L., Barnes, C. A., and Worley, P. F. (1999). Environment-specific expression of the immediate-early gene Arc in hippocampal neuronal ensembles. Nat. Neurosci. 2, 1120-1124.

Hartmann, H., Velbinger, K., Eckert, A., and Müller, W. E. (1996). Regionspecific downregulation of free intracellular calcium in the aged rat brain. Neurobiol. Aging 17, 557-563.

Henderson, V. W. (2009). Aging, estrogens, and episodic memory in women. Cogn. Behav. Neurol. 22, 205-214.

Herdegen, T., and Leah, J. D. (1998). Inducible and constitutive transcription factors in the mammalian nervous system: control of gene expression by Jun, Fos and Krox, and CREB/ATF proteins. Brain Res. Brain Res. Rev. 28, 370-490.

Hernandez, P. J., and Abel, T. (2008). The role of protein synthesis in memory consolidation: progress amid decades of debate. Neurobiol. Learn. Mem. 89, 293-311.

Hori, N., Hirotsu, I., Davis, P. J., and Carpenter, D. O. (1992). Long-term potentiation is lost in aged rats but preserved by calorie restriction. Neuroreport 3, 1085-1088.

Houston, F. P., Stevenson, G. D., McNaughton, B. L., and Barnes, C. A. (1999). Effects of age on the generalization and incubation of memory in the F344 rat. Learn. Mem. 6, 111-119.

Huang, Y., and Kandel, E. R. (2006). Agerelated enhancement of a protein synthesis-dependent late phase of LTP induced by low frequency paired-pulse stimulation in hippocampus. Learn. Mem. 13, 298-306.

Hughes, P. E., Alexi, T., Walton, M., Williams, C. E., Dragunow, M., Clark, R. G., and Gluckman, P. D. (1999). Activity and injury-dependent expression of inducible transcription factors, growth factors and apoptosis-related 
genes within the central nervous system. Prog. Neurobiol. 57, 421-450.

Igaz, L. M., Vianna, M. R. M., Medina, J. H., and Izquierdo, I. (2002). Two time periods of hippocampal mRNA synthesis are required for memory consolidation of fear-motivated learning. J. Neurosci. 22, 6781-6789.

Impey, S., Mark, M., Villacres, E. C., Poser, S., Chavkin, C., and Storm, D. R. (1996). Induction of CREmediated gene expression by stimuli that generate long-lasting LTP in area CA1 of the hippocampus. Neuron 16, 973-982.

Impey, S., Smith, D. M., Obrietan, K., Donahue, R., Wade, C., and Storm, D. R. (1998). Stimulation of cAMP response element (CRE)-mediated transcription during contextual learning. Nat. Neurosci. 1, 595-601.

Ingvar, M. C., Maeder, P., Sokoloff, L., and Smith, C. B. (1985). Effects of ageing on local rates of cerebral protein synthesis in Sprague-Dawley rats. Brain 108(Pt 1), 155-170.

Johnson, A., and Redish, A. D. (2007). Neural ensembles in CA3 transiently encode paths forward of the animal at a decision point. J. Neurosci. 27, 12176-12189.

Jones, M. W., Errington, M. L., French, P. J., Fine, A., Bliss, T. V., Garel, S., Charnay, P., Bozon, B., Laroche, S., and Davis, S. (2001). A requirement for the immediate early gene Zif268 in the expression of late LTP and long-term memories. Nat. Neurosci. 4, 289-296.

Karege, F., Lambercy, C., Schwald, M., Steimer, T., and Cissé, M. (2001a). Differential changes of cAMPdependent protein kinase activity and $3 \mathrm{H}$-cAMP binding sites in rat hippocampus during maturation and aging. Neurosci. Lett. 315, 89-92.

Karege, F., Schwald, M., Lambercy, C., Murama, J.J., Cisse, M., and Malafosse, A. (2001b).A non-radioactive assay for the cAMP-dependent protein kinase activity in rat brain homogenates and age-related changes in hippocampus and cortex. Brain Res. 903, 86-93.

Kelly, A., Mullany, P. M., and Lynch, M. A. (2000). Protein synthesis in entorhinal cortex and long-term potentiation in dentate gyrus. Hippocampus $10,431-437$.

Kemp, A., and Manahan-Vaughan, D. (2007). Hippocampal long-term depression: master or minion in declarative memory processes? Trends Neurosci. 30, 111-118.

Kentros, C., Hargreaves, E., Hawkins, R. D., Kandel, E. R., Shapiro, M., and Muller, R. V. (1998). Abolition of long-term stability of new hippocampal place cell maps by NMDA receptor blockade. Science 280, 2121-2126.
Kerr, D. S., Campbell, L.W., Hao, S. Y., and Landfield, P.W. (1989). Corticosteroid modulation of hippocampal potentials: increased effect with aging. Science 245, 1505-1509.

Kim, J. J., and Fanselow, M. S. (1992). Modality-specific retrograde amnesia of fear. Science 256, 675-677.

Kishimoto, Y., Suzuki, M., Kawahara, S., and Kirino, Y. (2001). Age-dependent impairment of delay and trace eyeblink conditioning in mice. Neuroreport 12 , 3349-3352.

Knuttinen, M. G., Gamelli, A. E., Weiss, C., Power, J. M., and Disterhoft, J. F. (2001). Age-related effects on eyeblink conditioning in the $\mathrm{F} 344 \times \mathrm{BN} \mathrm{F} 1$ hybrid rat. Neurobiol. Aging 22, 1-8.

Kogan, J. H., Frankland, P.W., and Silva, A. J. (2000). Long-term memory underlying hippocampus-dependent social recognition in mice. Hippocampus 10 , 47-56.

Krug, M., Lössner, B., and Ott, T. (1984). Anisomycin blocks the late phase of long-term potentiation in the dentate gyrus of freely moving rats. Brain Res. Bull. 13, 39-42.

Kudrimoti, H. S., Barnes, C. A., and McNaughton, B. L. (1999). Reactivation of hippocampal cell assemblies: effects of behavioral state, experience, and EEG dynamics. J. Neurosci. 19, 4090-4101.

Kuhn, H. G., Dickinson-Anson, H., and Gage, F. H. (1996). Neurogenesis in the dentate gyrus of the adult rat: age-related decrease of neuronal progenitor proliferation. J. Neurosci. 16, 2027-2033.

Kumar, A., and Foster, T. C. (2004). Enhanced long-term potentiation during aging is masked by processes involving intracellular calcium stores. J. Neurophysiol. 91, 2437-2444.

Kumar, A., and Foster, T. C. (2007). Shift in induction mechanisms underlies an age-dependent increase in DHPGinduced synaptic depression at CA3 CA1 synapses. J. Neurophysiol. 98, 2729-2736.

Kumar, A., Thinschmidt, J. S., Foster, T. C., and King, M. A. (2007). Aging effects on the limits and stability of long-term synaptic potentiation and depression in rat hippocampal area CA1. J. Neurophysiol. 98, 594-601.

Lanahan, A., Lyford, G., Stevenson, G. S. Worley, P. F., and Barnes, C. A. (1997). Selective alteration of long-term potentiation-induced transcriptional response in hippocampus of aged, memory-impaired rats. J. Neurosci. 17, 2876-2885.

Landfield, P. W. (1980). "Correlative studies of brain neurophysiology and behavior during aging," in The Psychobiology of Aging: Problems and
Perspectives, ed. D. Stein (New York, NY: Elsevier), 227-251.

Landfield, P. W. (1996). Aging-related increase in hippocampal calcium channels. Life Sci. 59, 399-404.

Landfield, P. W., and Lynch, G. (1977). Impaired monosynaptic potentiation in in vitro hippocampal slices from aged, memory-deficient rats. $J$. Gerontol. 32, 523-533.

Landfield, P. W., McGaugh, J. L., and Lynch, G. (1978). Impaired synaptic potentiation processes in the hippocampus of aged, memory-deficient rats. Brain Res. 150, 85-101.

Landfield, P. W., and Pitler, T. A. (1984). Prolonged Ca2+-dependent afterhyperpolarizations in hippocampal neurons of aged rats. Science 226, 1089-1092.

Lattal, K. M., Barrett, R. M., and Wood, M. A. (2007). Systemic or intrahippocampal delivery of histone deacetylase inhibitors facilitates fear extinction. Behav. Neurosci. 121, 1125-1131.

Lee, I., Rao, G., and Knierim, J. J. (2004). A double dissociation between hippocampal subfields: differential time course of CA3 and CA1 place cells for processing changed environments. Neuron 42, 803-815.

Leutgeb, S., and Leutgeb, J. K. (2007). Pattern separation, pattern completion, and new neuronal codes within a continuous CA3 map. Learn. Mem. $14,745-757$.

Leutgeb, S., Leutgeb, J. K., Moser, E. I., and Moser, M. (2006). Fast rate coding in hippocampal CA3 cell ensembles. Hippocampus 16, 765-774.

Leutgeb, S., Leutgeb, J. K., Treves, A. Moser, M., and Moser, E. I. (2004). Distinct ensemble codes in hippocampal areas CA3 and CA1. Science 305, 1295-1298.

Levy, W. B. (1989). A Computational Approach to Hippocampal Function. New York, NY: Academic Press.

Ling, D. S. F., Benardo, L. S., Serrano, P. A., Blace, N., Kelly, M. T., Crary, J. F., and Sacktor, T. C. (2002). Protein kinase Mzeta is necessary and sufficient for LTP maintenance. Nat. Neurosci. 5, 295-296.

Lisman, J., and Redish, A. D. (2009). Prediction, sequences and the hippocampus. Philos. Trans. R. Soc. Lond., B, Biol. Sci. 364, 1193-1201.

Lu, Y., Christian, K., and Lu, B. (2008). BDNF: a key regulator for protein synthesis-dependent LTP and longterm memory? Neurobiol. Learn. Mem. $89,312-323$.

Luine, V., Bowling, D., and Hearns, M. (1990).Spatial memory deficits in aged rats: contributions of monoaminergic systems. Brain Res. 537, 271-278.
Lyford, G. L., Yamagata, K., Kaufmann, W. E., Barnes, C. A., Sanders, L. K., Copeland, N. G., Gilbert, D. J., Jenkins, N. A., Lanahan, A. A., and Worley, P. F. (1995). Arc, a growth factor and activity-regulated gene, encodes a novel cytoskeleton-associated protein that is enriched in neuronal dendrites. Neuron 14, 433-445.

Lynch, M. A., and Voss, K. L. (1994). Membrane arachidonic acid concentration correlates with age and induction of long-term potentiation in the dentate gyrus in the rat. Eur. J. Neurosci. 6, 1008-1014.

Ma, L., Zablow, L., Kandel, E. R., and Siegelbaum, S. A. (1999). Cyclic AMP induces functional presynaptic boutons in hippocampal CA3-CA1 neuronal cultures. Nat. Neurosci. 2, 24-30.

Magnusson, K. R., Nelson, S. E., and Young, A. B. (2002). Age-related changes in the protein expression of subunits of the NMDA receptor. Brain Res. Mol. Brain Res. 99, 40-45.

Malgaroli, A., Ting, A. E., Wendland, B., Bergamaschi, A., Villa, A., Tsien, R. W., and Scheller, R. H. (1995). Presynaptic component of long-term potentiation visualized at individual hippocampal synapses. Science 268, 1624-1628.

Manahan-Vaughan, D., Kulla, A., and Frey, J. U. (2000). Requirement of translation but not transcription for the maintenance of long-term depression in the CA1 region of freely moving rats. J. Neurosci. 20, 8572-8576

Markus, E. J., Barnes, C. A., McNaughton, B. L., Gladden, V. L., and Skaggs, W. E. (1994). Spatial information content and reliability of hippocampal CA1 neurons: effects of visual input. Hippocampus 4, 410-421.

Marr,D. (1971). Simple memory: a theory for archicortex. Philos. Trans. R. Soc. Lond., B, Biol. Sci. 262, 23-81.

Matthies, H., and Reymann, K. G. (1993). Protein kinase A inhibitors prevent the maintenance of hippocampal long-term potentiation. Neuroreport 4, 712-714.

McGahon, B., Clements, M. P., and Lynch, M. A. (1997). The ability of aged rats to sustain long-term potentiation is restored when the age-related decrease in membrane arachidonic acid concentration is reversed. Neuroscience 81, 9-16.

McIntyre, J. S., and Craik, F. I. (1987). Age differences in memory for item and source information. Can. J. Psychol. 41, 175-192.

McMonagle-Strucko, K., and Fanelli, R. J. (1993). Enhanced acquisition of reversal training in a spatial learning task in rats treated with chronic 
nimodipine. Pharmacol. Biochem. Behav. 44, 827-835.

McNaughton, B. L., Barnes, C. A., Battaglia, F. P., Bower, M. R., Cowen, S. L., Ekstrom, A. D., Hoffman, K. L., Houston, F. P., Karten, Y., Lipa, P., Pennartz, C. M. A., and Sutherland, G. R. (2003). Off-line reprocessing of recent memory and its role in memory consolidation: a progress report. In Sleep and brain plasticity, B. Stickgold, ed. (Oxford, UK: Oxford University Press), pp. 225-246.

McNaughton, B. L., Barnes, C. A., Gerrard, J. L., Gothard, K., Jung, M. W., Knierim, J. J., Kudrimoti, H., Qin, Y., Skaggs, W. E., Suster, M., Weaver, K. L. (1996). Deciphering the hippocampal polyglot: the hippocampus as a path integration system. J. Exp. Biol. 199, 173-185.

McNaughton, B. L., and Morris, R. G. M. (1987). Hippocampal synaptic enhancement and information storage within a distributed memory system. Trends Neurosci. 10, 408-415.

Mehta, M. R., Barnes, C. A., and McNaughton, B.L. (1997). Experiencedependent, asymmetric expansion of hippocampal place fields. Proc. Natl. Acad. Sci. U.S.A. 94, 8918-8921.

Mehta, M. R., Quirk, M. C., and Wilson, M. A. (2000). Experience-dependent asymmetric shape of hippocampal receptive fields. Neuron 25, 707-715.

Mizumori, S.J., Lavoie, A. M., and Kalyani, A. (1996). Redistribution of spatial representation in the hippocampus of aged rats performing a spatial memory task. Behav. Neurosci. 110, 1006-1016.

Mizumori, S. J., Rosenzweig, M. R., and Bennett, E. L. (1985). Long-term working memory in the rat: effects of hippocampally applied anisomycin. Behav. Neurosci. 99, 220-232.

Mizuno, T., Kanazawa, I., and Sakurai, M. (2001). Differential induction of LTP and LTD is not determined solely by instantaneous calcium concentration: an essential involvement of a temporal factor. Eur. J. Neurosci. 14, 701-708.

Montarolo, P. G., Goelet, P., Castellucci, V. F., Morgan, J., Kandel, E. R., and Schacher, S. (1986). A critical period for macromolecular synthesis in longterm heterosynaptic facilitation in Aplysia. Science 234, 1249-1254.

Monti, B., Berteotti, C., and Contestabile, A. (2005). Dysregulation of memoryrelated proteins in the hippocampus of aged rats and their relation with cognitive impairment. Hippocampus 15, 1041-1049.

Moore, C. I., Browning, M. D., and Rose, G. M. (1993). Hippocampal plasticity induced by primed burst, but not long-term potentiation, stimulation is impaired in area $\mathrm{CA} 1$ of aged Fischer 344 rats. Hippocampus 3, 57-66.

Morgan, J. I., Cohen, D. R., Hempstead, J. L., and Curran, T. (1987). Mapping patterns of $\mathrm{c}$-fos expression in the central nervous system after seizure. Science 237, 192-197.

Morgan, J. I., and Curran, T. (1991). Stimulus-transcription coupling in the nervous system: involvement of the inducible proto-oncogenes fos and jun. Annu. Rev. Neurosci. 14, 421-451.

Mouravlev, A., Dunning, J., Young, D., and During, M. J. (2006). Somatic gene transfer of cAMP response elementbinding protein attenuates memory impairment in aging rats. Proc. Natl. Acad. Sci. U.S.A. 103, 4705-4710.

Mullany, P., and Lynch, M. A. (1997). Changes in protein synthesis and synthesis of the synaptic vesicle protein, synaptophysin, in entorhinal cortex following induction of long-term potentiation in dentate gyrus: an age-related study in the rat. Neuropharmacology 36, 973-980.

Murray, C. A., and Lynch, M. A. (1998a). Dietary supplementation with vitamin E reverses the age-related deficit in long term potentiation in dentate gyrus. J. Biol. Chem. 273, 12161-12168.

Murray, C. A., and Lynch, M. A. (1998b). Evidence that increased hippocampal expression of the cytokine interleukin- 1 beta is a common trigger for age- and stress-induced impairments in long-term potentiation. J. Neurosci. 18, 2974-2981.

Nguyen, P. V., Abel, T., and Kandel, E. R. (1994). Requirement of a critical period of transcription for induction of a late phase of LTP. Science 265, 1104-1107.

Niehof, M., Manns, M. P., and Trautwein, C. (1997). CREB controls LAP/C/EBP beta transcription. Mol. Cell. Biol. 17, 3600-3613.

Norris, C. M., Korol, D. L., and Foster, T. C. (1996). Increased susceptibility to induction of long-term depression and long-term potentiation reversal during aging. J. Neurosci. 16, 5382-5392.

Oler, J. A., and Markus, E. J. (1998). Agerelated deficits on the radial maze and in fear conditioning: hippocampal processing and consolidation. Hippocampus 8, 402-415.

Otani, S., Marshall, C. J., Tate, W. P., Goddard, G. V., and Abraham, W. C. (1989). Maintenance of long-term potentiation in rat dentate gyrus requires protein synthesis but not messenger RNA synthesis immediately post-tetanization. Neuroscience 28, 519-526.

Otani, S., Roisin-Lallemand, M. P., and Ben-Ari, Y. (1992). Enhancement of extracellular protein concentrations during long-term potentiation in the rat hippocampal slice. Neuroscience 47, 265-272.

Pang, P. T., and Lu, B. (2004). Regulation of late-phase LTP and long-term memory in normal and aging hippocampus: role of secreted proteins tPA and BDNF. Ageing Res. Rev. 3, 407-430.

Parsons, C. G., Quack, G., Bresink, I., Baran, L., Przegalinski, E., Kostowski, W., Krzascik, P., Hartmann, S., and Danysz, W. (1995). Comparison of the potency, kinetics and voltagedependency of a series of uncompetitive NMDA receptor antagonists in vitro with anticonvulsive and motor impairment activity in vivo. Neuropharmacology 34, 1239-1258.

Parsons, C. G., Stöffler, A., and Danysz, W. (2007). Memantine: a NMDA receptor antagonist that improves memory by restoration of homeostasis in the glutamatergic system-too little activation is bad, too much is even worse. Neuropharmacology 53, 699-723.

Pastalkova, E., Serrano, P., Pinkhasova, D., Wallace, E., Fenton, A. A., and Sacktor, T. C. (2006). Storage of spatial information by the maintenance mechanism of LTP. Science 313, 1141-1144.

Pavlides, C., and Winson, J. (1989). Influences of hippocampal place cell firing in the awake state on the activity of these cells during subsequent sleep episodes. J. Neurosci. 9, 2907-2918.

Penner, M. R., Roth, T. L., Chawla, M. K., Hoang, L. T., Roth, E. D., Lubin, F. D., Sweatt, D. J., Worley, P. F., and Barnes, C. A. (2010a). Age-related changes in Arc transcription and DNA methylation within the hippocampus. Neurobiol. Aging. (inpress)

Penner, M. R., Roth, T. L., Barnes, C. A., and Sweatt, J.D. (2010b). An epigenetic hypothesis of aging-related cognitive dysfunction. Front. Aging Neurosci. 2:9. doi:10.3389/fnagi.2010.00009.

Peretti, C. S., Gierski, F., and Harrois, S. (2004). Cognitive skill learning in healthy older adults after 2 months of double-blind treatment with piribedil. Psychopharmacology (Berl.) 176, 175-181.

Peskind, E. R., Potkin, S. G., Pomara, N., Ott, B. R., Graham, S. M., Olin, J. T., and McDonald, S. (2006). Memantine treatment in mild to moderate Alzheimer disease: a 24-week randomized, controlled trial. Am. J. Geriatr. Psychiatry 14, 704-715.

Petrovich, G. D., Holland, P. C., and Gallagher, M. (2005). Amygdalar and prefrontal pathways to the lateral hypothalamus are activated by a learned cue that stimulates eating. $J$. Neurosci. 25, 8295-8302.
Pinaud, R., Penner, M. R., Robertson, H. A., and Currie, R. W. (2001). Upregulation of the immediate early gene arc in the brains of rats exposed to environmental enrichment: implications for molecular plasticity. Brain Res. Mol. Brain Res. 91, 50-56.

Pitler, T. A., and Landfield, P. W. (1990). Aging-related prolongation of calcium spike duration in rat hippocampal slice neurons. Brain Res. 508, $1-6$.

Porte, Y., Buhot, M., and Mons, N. (2008). Alteration of CREB phosphorylation and spatial memory deficits in aged 129T2/Sv mice. Neurobiol. Aging 29, 1533-1546.

Quevedo, J.A., Vianna, M. R. M., Martins, M. R., Barichello, T., Medina, J. H., Roesler, R., and Izquierdo, I. (2004). Protein synthesis, PKA, and MAP kinase are differentially involved in short- and long-term memory in rats. Behav. Brain Res. 154, 339-343.

Rao, G., Barnes, C. A., McNaughton, B. L., and Shen, J. (1994). Age-related decrease in the NMDA-mediated EPSP in FD. Abstr. - Soc. Neurosci. 20, 1207.

Rapp, P. R., Rosenberg, R. A., and Gallagher, M. (1987). An evaluation of spatial information processing in aged rats. Behav. Neurosci. 101, 3-12.

Raymond, C. R., Thompson, V. L., Tate, W. P., and Abraham, W. C. (2000). Metabotropic glutamate receptors trigger homosynaptic protein synthesis to prolong long-term potentiation. J. Neurosci. 20, 969-976.

Redish, A. D., and Touretzky, D. S. (1998). The role of the hippocampus in solving the Morris water maze. Neural. Comput. 10, 73-111.

Richardson, A. (1981). "The relationship between aging and protein synthesis," in CRC Handbook of Biochemistry in Aging, ed. J. R. Florini (Boca Raton, FL: CRC Press), 79-101.

Richardson, A., and Birchenall-Sparks, M. C. (1983). Age-related changes in protein synthesis. Rev. Biol. Res. Aging 1, 255-273.

Richardson, A., Birchenall-Sparks, M. C., and Staecker, J. L. (1983). Aging and transcription. Rev. Biol. Res. Aging 1, 275-294.

Richardson, C. L., Tate, W. P., Mason, S. E., Lawlor, P. A., Dragunow, M., and Abraham, W. C. (1992). Correlation between the induction of an immediate early gene, zif/268, and long-term potentiation in the dentate gyrus. Brain Res. 580, 147-154.

Rogawski, M. A., and Wenk, G. L. (2003). The neuropharmacological basis for the use of memantine in the treatment of Alzheimer's disease. CNS Drug Rev. 9, 275-308. 
Rosenzweig, E. S., and Barnes, C.A. (2003). Impact of aging on hippocampal function: plasticity, network dynamics, and cognition. Prog. Neurobiol. 69, 143-179.

Rosenzweig, E. S., Rao, G., McNaughton, B. L., and Barnes, C. A. (1997). Role of temporal summation in age-related long-term potentiation-induction deficits. Hippocampus 7, 549-558.

Rosenzweig, E. S., Redish, A. D., McNaughton, B. L., and Barnes, C. A. (2003). Hippocampal map realignment and spatial learning. Nat. Neurosci. 6, 609-615.

Ryan, T. A., Ziv, N. E., and Smith, S. J. (1996). Potentiation of evoked vesicle turnover at individually resolved synaptic boutons. Neuron 17, 125-134.

Sajikumar, S., and Frey, J. U. (2004). Lateassociativity, synaptic tagging, and the role of dopamine during LTP and LTD. Neurobiol Learn Mem 82, 12-25.

Schneider, A., Huentelman, M. J., Kremerskothen, J., Duning, K., Spoelgen, R., and Nikolich, K. (2010). KIBRA: a new gateway to learning and memory? Front. Aging Neurosci. 2:4. doi:10.3389/neuro.24.004.2010.

Schulz, S., Siemer, H., Krug, M., and Höllt, V. (1999). Direct evidence for biphasic cAMP responsive elementbinding protein phosphorylation during long-term potentiation in the rat dentate gyrus in vivo. J. Neurosci. 19, 5683-5692.

Scoville, W. B., and Milner, B. (1957). Loss of recent memory after bilateral hippocampal lesions. J. Neurol. Neurosurg. Psychiatr. 20, 11-21.

Scriabine, A., Schuurman, T., and Traber, J. (1989). Pharmacological basis for the use of nimodipine in central nervous system disorders. FASEB J. 3, 1799-1806.

Shankar, S., Teyler, T. J., and Robbins, N. (1998).Aging differentially alters forms of long-term potentiation in rat hippocampal area CA1. J. Neurophysiol. 79, 334-341.

Shaywitz, A. J., and Greenberg, M. E. (1999). CREB: a stimulus-induced transcription factor activated by a diverse array of extracellular signals. Annu. Rev. Biochem. 68, 821-861.

Shema, R., Sacktor, T. C., and Dudai, Y. (2007). Rapid erasure of long-term memory associations in the cortex by an inhibitor of PKM zeta. Science 317, 951-953.

Shen, J., Barnes, C. A., McNaughton, B. L., Skaggs, W. E., and Weaver, K. L. (1997). The effect of aging on experience-dependent plasticity of hippocampal place cells. J. Neurosci. 17, 6769-6782.

Sheng, M., and Greenberg, M. E. (1990). The regulation and function of $\mathrm{c}$-fos and other immediate early genes in the nervous system. Neuron 4, 477-485.

Shimada, A., Mukhin, A., Ingram, D. K., and London, E. D. (1997). N-methyl$\mathrm{D}$-aspartate receptor binding in brains of rats at different ages. Neurobiol. Aging 18, 329-333.

Shouval, H. Z., Castellani, G. C., Blais, B. S., Yeung, L. C., and Cooper, L. N. (2002). Converging evidence for a simplified biophysical model of synaptic plasticity. Biol. Cybern. 87 , 383-391.

Silva, A. J., Kogan, J. H., Frankland, P. W., and Kida, S. (1998). CREB and memory. Annu. Rev. Neurosci. 21, 127-148.

Small, S. A., Chawla, M. K., Buonocore, M., Rapp, P. R., and Barnes, C. A. (2004). Imaging correlates of brain function in monkeys and rats isolates a hippocampal subregion differentially vulnerable to aging. Proc. Natl. Acad. Sci. U.S.A. 101, 7181-7186.

Small, S. A., Tsai, W. Y., DeLaPaz, R., Mayeux, R., and Stern, Y. (2002). Imaging hippocampal function across the human life span: is memory decline normal or not? Ann. Neurol. 51, 290-295.

Smith, C. B., Sun, Y., and Sokoloff, L. (1995). Effects of aging on regional rates of cerebral protein synthesis in the Sprague-Dawley rat: examination of the influence of recycling of amino acids derived from protein degradation into the precursor pool. Neurochem. Int. 27, 407-416.

Solomon, P. R., and Groccia-Ellison, M. E. (1996). Classic conditioning in aged rabbits: delay, trace, and longdelay conditioning. Behav. Neurosci. 110, 427-435.

Spencer, W. D., and Raz, N. (1995). Differential effects of aging on memory for content and context: a metaanalysis. Psychol. Aging 10, 527-539.

Squire, L. R., and Barondes, S. H. (1973). Memory impairment during prolonged training in mice given inhibitors of cerebral protein synthesis. Brain Res. 56, 215-225.

Stanton, P. K., and Sarvey, J. M. (1984). Blockade of long-term potentiation in rat hippocampal CA1 region by inhibitors of protein synthesis. J. Neurosci. 4, 3080-3088.

Steward, O., Wallace, C. S., Lyford, G. L., and Worley, P. F. (1998). Synaptic activation causes the mRNA for the IEG Arc to localize selectively near activated postsynaptic sites on dendrites. Neuron 21, 741-751.

Steward, O., and Worley, P. F. (2001). Selective targeting of newly synthesized Arc mRNA to active synapses requires NMDA receptor activation. Neuron 30, 227-240.
Straube, K. T., Deyo, R. A., Moyer, J., and Disterhoft, J. F. (1990). Dietary nimodipine improves associative learning in aging rabbits. Neurobiol. Aging 11, 659-661.

Tagawa, Y., Kanold, P. O., Majdan, M., and Shatz, C. J. (2005). Multiple periods of functional ocular dominance plasticity in mouse visual cortex. Nat. Neurosci. 8, 380-388.

Tamaru, M., Yoneda, Y., Ogita, K., Shimizu, J., and Nagata, Y. (1991). Age-related decreases of the N-methyl-D-aspartate receptor complex in the rat cerebral cortex and hippocampus. Brain Res. 542, 83-90.

Tan, A., Moratalla, R., Lyford, G. L. Worley, P., and Graybiel, A. M. (2000). The activity-regulated cytoskeletalassociated protein arc is expressed in different striosome-matrix patterns following exposure to amphetamine and cocaine. J. Neurochem. 74, 2074-2078.

Taubenfeld, S. M., Wiig, K. A., Bear, M. F., and Alberini, C. M. (1999). A molecular correlate of memory and amnesia in the hippocampus. Nat. Neurosci. 2, 309-310.

Thibault, O., and Landfield, P. W. (1996). Increase in single L-type calcium channels in hippocampal neurons during aging. Science 272, 1017-1020.

Thompson, L. T., and Best, P. J. (1990). Long-term stability of the placefield activity of single units recorded from the dorsal hippocampus of freely behaving rats. Brain Res. 509, 299-308.

Thompson, L. T., Moyer, J., and Disterhoft, J. F. (1996). Trace eyeblink conditioning in rabbits demonstrates heterogeneity of learning ability both between and within age groups. Neurobiol. Aging 17, 619-629.

Tielen, A. M., Mollevanger, W. J., Lopes da Silva, F. H., and Hollander, C. F. (1983) "Neuronal plasticity in hippocampal slices of extremely old rats," in Aging of the Brain, eds W. H. Gispen and J. Traber (New York, NY: Elsevier), 73-84.

Touretzky, D. S., and Redish, A. D. (1996). Theory of rodent navigation based on interacting representations of space. Hippocampus 6, 247-270.

Touzani, K., Marighetto, A., and Jaffard, R. (2003). Fos imaging reveals ageing-related changes in hippocampal response to radial maze discrimination testing in mice. Eur. J. Neurosci. 17, 628-640.

Tully, T., Bourtchouladze, R., Scott, R., and Tallman, J. (2003). Targeting the CREB pathway for memory enhancers. Nat. Rev. Drug Discov. 2, 267-277.

Van der Zee, E. A., Palm, I. F., O'Connor, M., Maizels, E. T., Hunzicker-Dunn,
M., and Disterhoft, J. F. (2004). Agingrelated alterations in the distribution of $\mathrm{Ca}(2+)$-dependent $\mathrm{PKC}$ isoforms in rabbit hippocampus. Hippocampus 14, 849-860.

Vazdarjanova, A., and Guzowski, J. F. (2004). Differences in hippocampal neuronal population responses to modifications of an environmental context: evidence for distinct, yet complementary, functions of CA3 and CA1 ensembles. J. Neurosci. 24 6489-6496.

Vecsey, C. G., Hawk, J. D., Lattal, K. M., Stein, J. M., Fabian, S. A., Attner, M. A., Cabrera, S. M., McDonough, C. B., Brindle, P. K., Abel, T., and Wood, M. A. (2007). Histone deacetylase inhibitors enhance memory and synaptic plasticity via CREB:CBP-dependent transcriptional activation. J. Neurosci. 27, 6128-6140.

Wallace, C. S., Lyford, G. L., Worley, P. F., and Steward, O. (1998). Differential intracellular sorting of immediate early gene mRNAs depends on signals in the mRNA sequence. J. Neurosci. 18, 26-35.

Wallace, C. S., Withers, G. S., Weiler, I. J., George, J. M., Clayton, D. F., and Greenough, W. T. (1995). Correspondence between sites of NGFI-A induction and sites of morphological plasticity following exposure to environmental complexity. Brain Res. Mol. Brain Res. 32, 211-220.

Ward, M. T., Oler, J. A., and Markus, E. J. (1999). Hippocampal dysfunction during aging I: deficits in memory consolidation. Neurobiol. Aging 20, 363-372.

Webster, G. C. (1985). "Protein synthesis in aging organisms," in Molecular Biology of Aging: Gene Stability and Gene Expression, eds R. S. Sohal, L. S. Birnbaum, and R. G. Cutler (New York: Raven Press), 263-289.

Wenk, G. L., and Barnes, C. A. (2000). Regional changes in the hippocampal density of AMPA and NMDA receptors across the lifespan of the rat. Brain Res. 885, 1-5.

Wenk, G. L., Walker, L. C., Price, D. L., and Cork, L. C. (1991). Loss of NMDA, but not GABA-A, binding in the brains of aged rats and monkeys. Neurobiol. Aging 12, 93-98.

Whitlock, J. R., Heynen, A. J., Shuler, M. G., and Bear,M.F.(2006).Learning induces long-term potentiation in the hippocampus. Science 313, 1093-1097.

Williams, B., Granholm, A., and Sambamurti, K. (2007). Agedependent loss of NGF signaling in the rat basal forebrain is due to disrupted MAPK activation. Neurosci. Lett. 413, 110-114. 
Williams, B. J., Bimonte-Nelson,H.A., and Granholm-Bentley, A. (2006). ERKmediated NGF signaling in the rat septo-hippocampal pathway diminishes with age. Psychopharmacology (Berl.) 188, 605-618.

Wilson, I. A., Ikonen, S., Gallagher, M., Eichenbaum, H., and Tanila, H. (2005). Age-associated alterations of hippocampal place cells are subregion specific. J. Neurosci. 25, 6877-6886.

Wilson, M. A., and McNaughton, B. L. (1993). Dynamics of the hippocampal ensemble code for space. Science 261, 1055-1058.

Wilson, M. A., and McNaughton, B. L. (1994). Reactivation of hippocampal ensemble memories during sleep. Science 265, 676-679.

Winocur, G. (1988a). A neuropsychological analysis of memory loss with age. Neurobiol. Aging 9, 487-494.

Winocur, G. (1988b). Long-term memory loss in senescent rats: neuropsychological analysis of interference and context effects. Psychol. Aging 3, 273-279.

Winocur, G. (1990). Anterograde and retrograde amnesia in rats with dorsal hippocampal or dorsomedial thalamic lesions. Behav. Brain Res. 38, 145-154.

Worley, P. F., Bhat, R. V., Baraban, J. M., Erickson, C. A., McNaughton, B. L., and Barnes, C. A. (1993). Thresholds for synaptic activation of transcription factors in hippocampus: correlation with long-term enhancement. $J$. Neurosci. 13, 4776-4786.

Yan, J., Zhang, Y., Roder, J., and McDonald, R. J. (2003). Aging effects on spatial tuning of hippocampal place cells in mice. Exp. Brain Res. 150, 184-193.

Yang, J. W., Liu, D. S., and Richardson, A. (1977). Biochemical studies of chick brain development and maturation: I. Alterations in the macromolecule content and cell-free protein synthesis. Mech. Ageing Dev. 6, 77-93.
Yang, S. N., Tang, Y. G., and Zucker, R. S. (1999). Selective induction of LTP and LTD by postsynaptic [Ca2 + ]i elevation. J. Neurophysiol. 81, 781-787.

Yashiro, K., and Philpot, B. D. (2008). Regulation of NMDA receptor subunit expression and its implications for LTD, LTP, and metaplasticity. Neuropharmacology 55, 1081-1094.

Yau, J. L., Olsson, T., Morris, R. G., Noble, J., and Seckl, J. R. (1996). Decreased NGFI-A gene expression in the hippocampus of cognitively impaired aged rats. Brain Res. Mol. Brain Res. 42, 354-357.

Yin, J. C., and Tully, T. (1996). CREB and the formation of long-term memory. Curr. Opin. Neurobiol. 6, 264-268.

Zola-Morgan, S. M., and Squire, L. R. (1990). The primate hippocampal formation: evidence for a time-limited role in memory storage. Science 250, 288-290.

Zou, Z., and Buck, L. B. (2006). Combinatorial effects of odorant mixes in olfactory cortex. Science 311, 1477-1481.

Conflict of Interest Statement: The authors declare that the research was conducted in the absence of any commercial or financial relationships that could be construed as a potential conflict of interest.

Received: 17 December 2009; paper pending published: 29 March 2010; accepted: 15 June 2010; published online: 06 August 2010. Citation: Schimanski LA and Barnes CA (2010) Neural protein synthesis during aging: effects on plasticity and memory. Front. Ag. Neurosci. 2:26. doi: 10.3389/ fnagi.2010.00026

Copyright $\odot 2010$ Schimanski and Barnes. This is an open-access article subject to an exclusive license agreement between the authors and the Frontiers Research Foundation, which permits unrestricted use, distribution, and reproduction in any medium, provided the original authors and source are credited. 